A thematic paper supporting the OECD DAC INCAF project

'Global Factors Influencing the Risk of Conflict and Fragility'

\title{
From spoilers to statebuilders: Constructive approaches to engagement with non-state armed groups in fragile states
}

Sukanya Podder

Cranfield University

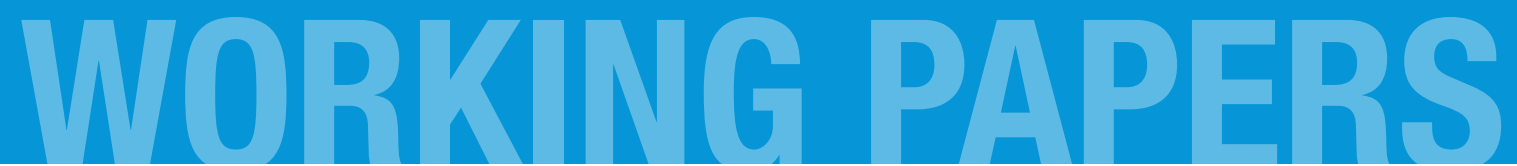

The Development Assistance Committee: Enabling effective development 
This work is published on the responsibility of the Secretary-General of the Organisation for Economic Cooperation and Development (OECD). The opinions expressed and arguments employed herein do not necessarily reflect the official views of the Organisation or of the governments of its member countries.

This document and any map included herein are without prejudice to the status of or sovereignty over any territory, to the delimitation of international frontiers and boundaries and to the name of any territory, city or area.

\section{Note to the reader}

This paper is one of eight thematic papers supporting the OECD DAC INCAF project on Global Factors Influencing the Risk of Conflict and Fragility. Each paper explores a specific global factor. The synthesis report, Think Global, Act Global: Confronting global factors influencing conflict and fragility (OECD, 2012), can be found at:

\section{www.oecd.org/dac/conflictandfragility/globalfactors.htm}

While the thematic papers have been subjected to a robust peer review process, they remain working papers rather than for publication in peer-reviewed journals. 


\begin{abstract}
The global policy discourse and the war on terror tend to ignore the wide variety of roles and agendas of non-state armed groups (NSAGs), viewing them primarily as threats to security, negative for peace and as important spoilers that can undermine successful peace building. They tend to be closely linked with other forms of transnational threats such as international terrorism, crime, narcotics, human trafficking, and the illicit trade in small arms. The paper argues that engaging with NSAGs on the basis of their positive or potentially positive impacts is more productive. It emphasises the importance of distinguishing different types of NSAG and understanding their motivation, mobilisation, financing and popular support in order to assess their claims to legitimacy. Potential entry points and policy guidelines for donors include the need for "bottom-up" statebuilding efforts in capacity trap countries like Afghanistan and DRC, the inclusion of legitimate groups in peace settlements and greater focus on the positive role of NSAGs in statebuilding. Finally, for statebuilding efforts to be successful they must be framed within a broader template of regional peacebuilding to prevent the externalisation or spillover of conflict and fragility.
\end{abstract}




\section{Table of Contents}

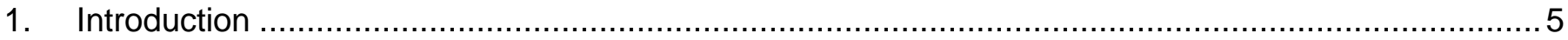

2. Key dimensions and developments ..................

2.1. The links between fragility, legitimacy and non-state armed groups ...............................................

2.2. The factors which contribute to NSAG formation .....................................................................

2.3. The key dimensions of NSAGs: A typology ………

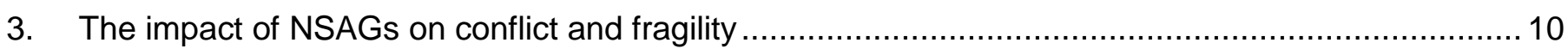

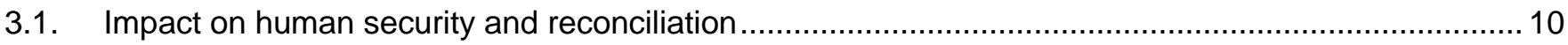

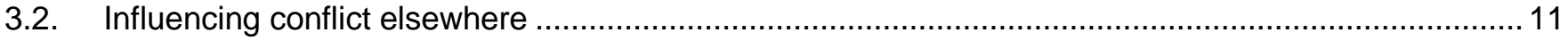

3.3. Potential positive impacts: popular support, legitimacy and governance ………........................... 13

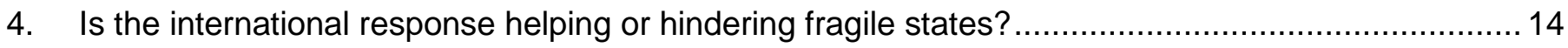

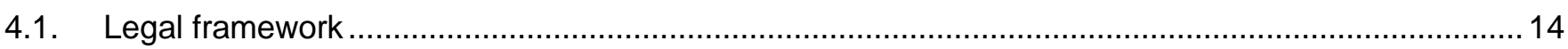

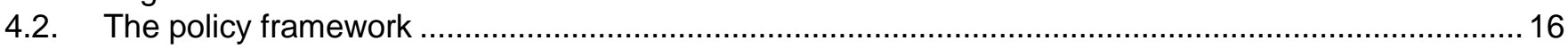

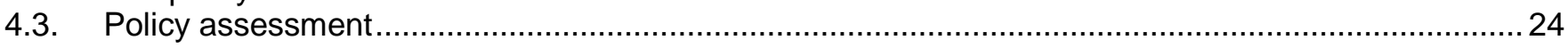

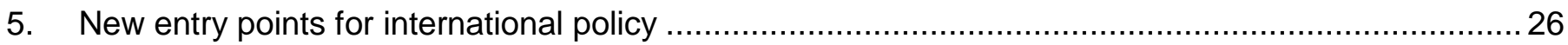

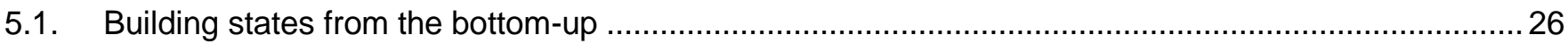

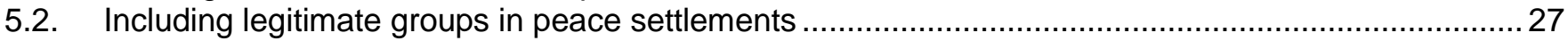

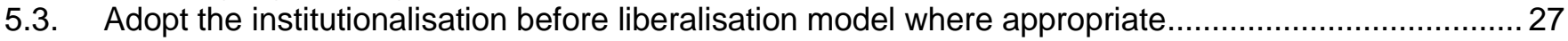

5.4. Focus on the positive role of NSAGs in statebuilding .............................................................. 28

5.5. Acknowledging the importance of regional peacebuilding in successful statebuilding ...................... 28

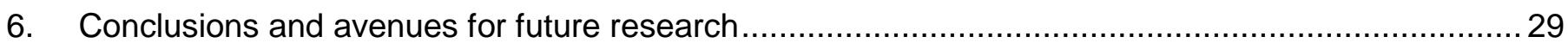

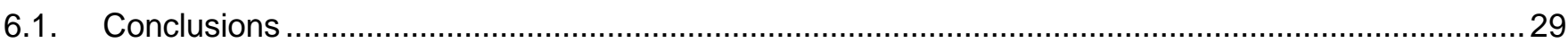

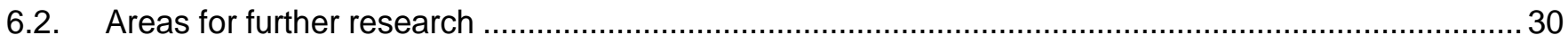

Boxes

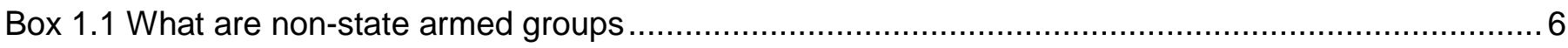

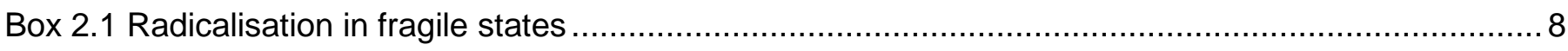

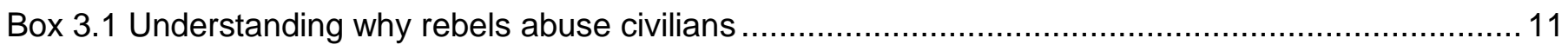

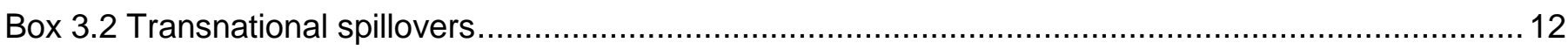

Box 4.1 Being more nuanced in humanitarian work with NSAGs: the case of Somalia........................... 18

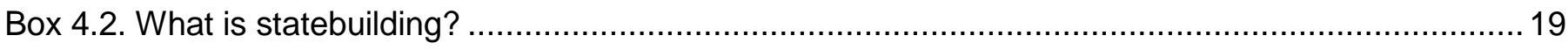

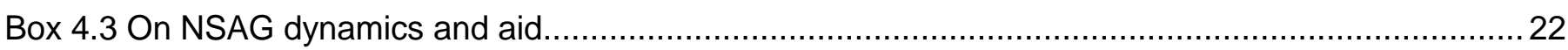

\section{Tables}

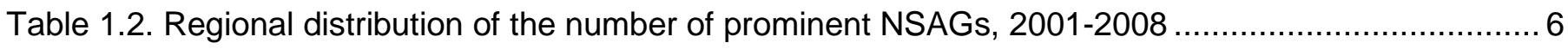

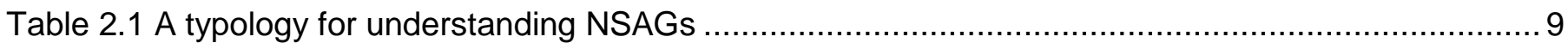




\section{Acronyms and abbreviations}

\begin{tabular}{|c|c|}
\hline ASEAN & Association of Southeast Asian Nations \\
\hline $\mathrm{AU}$ & African Union \\
\hline CAR & Central African Republic \\
\hline DDR & Disarmament, demobilisation and reintegration \\
\hline DRC & Democratic Republic of Congo \\
\hline ECOWAS & Economic Community of West African States \\
\hline EISF & European Interagency Security Forum \\
\hline FCAS & Fragile and conflict-affected states \\
\hline GWOT & Global war on terror \\
\hline ICOC & International Code of Conduct for Private Security Providers \\
\hline IMO & International Maritime Organisation \\
\hline INGO & international non-governmental organisations \\
\hline ISOA & International Stability Operations Association \\
\hline LTEE & Liberation Tigers of Tamil Eelam \\
\hline NATO & North Atlantic Treaty Organisation \\
\hline NSAG & Non-state armed groups \\
\hline OSCE & Organisation for Security and Co-operation in Europe \\
\hline PMSC & Private military and security companies \\
\hline PSC & Private security company \\
\hline PSP & Private security providers \\
\hline SALW & Small arms and light weapons \\
\hline SPLA & Sudan People's Liberation Army \\
\hline TFG & Transitional Federal Government (Somalia) \\
\hline UNSC & UN Security Council \\
\hline UNSCR & UN Security Council Resolution \\
\hline WTO & World Trade Organization \\
\hline
\end{tabular}




\section{Introduction}

International engagement strategies for non-state armed groups (NSAGs; see Box 1.1) - either as part of peace negotiations or for effective humanitarian and developmental activities - have gained priority in global policy thinking on fragile and conflict-affected states (FCAS) of late. FCAS are complex socioeconomic environments that may be characterised by the presence of more than one type of NSAG and may provide ideal locations for their germination and growth. Advances in technology and communications, as well as in the global political economy, have brought about important changes in the nature, locations and actors involved in conflict. This has implications for processes of mobilisation and armed group formation, the provision of public services, performance of governance functions, the nature and use of violence on civilian targets, and strategies of financing to achieve group objectives.

The continuing expansion in the scope of their definition (Box 1.1) has resulted in NSAGs being closely linked with other forms of transnational threats such as diaspora politics, international terrorism, crime, narcotics, human trafficking, and the illicit trade in small arms. Table 1.1 illustrates the regional distribution of prominent NSAGs between 2001 and 2008. The Middle East and North Africa, Sub-Saharan African and Central and South Asian regions have seen a progressive expansion in the number of active NSAGs. Global policy discourse tends to ignore the wide variety of NSAG roles and agendas, both positive and negative, and views them primarily as threats to security, and as important spoilers that can create impediments to successful peace building. While these inter-linkages are acknowledged as critical they remain to be defined and will be explored later in this paper to understand the global threat dimension of NSAGs.

While there is compelling evidence of the negative impacts that NSAGs can have on conflict and fragility, in some cases NSAGs may offer protection to civilians from state-sponsored violence (against specific ethnic, religious or tribal groups) and can co-operate with the international community in enhancing civilian protection and humanitarian support in fragile and conflict-affected environments. Their aim can be both territorial control and political legitimacy. They may use a range of strategies to secure support, both domestically and externally, and can undertake important governance and statebuilding functions to demonstrate capability and reach. NSAGs may also engage or co-operate with other governments as well other non-state armed actors (nationally and transnationally) in developing their own legitimacy. 


\section{Box 1.1 What are non-state armed groups}

Before engaging with NSAGs there must be agreement about what they are. However, there is little clarity as to what actually constitutes a NSAG. The International Council on Human Rights Policy defines NSAGs as groups that are "armed and use force to achieve their objectives and are not under state control" (Hofmann, 2006: 396). It associates NSAGs with economic and political goals rather than private agendas. This definition does not include either the private security firms that have proliferated or organised crime cartels. However, recent international relations and security literature has advocated inclusion of criminal gangs, mercenaries, terrorists and private security contractors within this broad umbrella term (Rodgers and Muggah, 2010; Hazen, 2010). In a recent Horizon 2015 document, the Geneva Centre for the Democratic Control of Armed Forces has grouped together all of the above as well as militias and vigilante groups as new forms of NSAG threat (DCAF and Geneva Call and DCAF, 2011).

In this paper, "NSAGs" are defined to broadly include groups that possess a hierarchical organisation, use violence for political ends, are independent from state control and have some degree of territorial control over a geographic area (Bruderlein, 2000; Policzer 2005). State sponsored paramilitaries/progovernment militias and transnational terrorist groups like $A /$ Qaeda can also be included within this definition (Hofmann, 2004; Policzer, 2005; Dudouet, 2007; Bruderlein, 2000).

This paper will analyse some effects of international engagement with NSAGs on conflict and fragility in the context of peace and statebuilding support. The paper is organised as follows. Section 2 outlines some key dimensions contributing to the development of NSAGs, while Section 3 analyses the importance and impact of NSAGs in the context of fragility and conflict. The fourth section examines international policy and legal responses to date, concentrating on key developments and assessing strengths and weaknesses. Section 5 looks at possible entry points for policy to mitigate the impact of NSAGs on FCAS in the future and involve them more in peacebuilding and statebuilding. The last section offers overall conclusions and identifies possible areas for further research.

Table 1.1. Regional distribution of the number of prominent NSAGs, 2001-2008

\begin{tabular}{lcccccccc}
\hline Region & $2001-$ & $2002-$ & $2003-$ & $2004-$ & $2005-$ & 2006 & 2007 & 2008 \\
& 02 & 03 & 04 & 05 & 06 & & & \\
\hline Europe & & & & & & & & \\
(NATO- and Non-NATO) & 15 & 17 & 22 & 30 & 37 & 47 & 42 & 52 \\
Russia & 01 & 01 & 04 & 04 & 06 & - & 08 & 12 \\
Middle East and North Africa & 22 & 24 & 33 & 50 & 65 & 71 & 71 & 81 \\
Central and South Asia & 10 & 21 & 26 & 73 & 74 & 83 & 84 & 86 \\
East Asia and Australia & 21 & 25 & 31 & 33 & 36 & 40 & 40 & 41 \\
Carribbean and Latin America & 06 & 06 & 10 & 09 & 14 & 15 & 15 & 16 \\
Sub Saharan Africa & 21 & 34 & 44 & 64 & 58 & 83 & 84 & 108 \\
North America & - & - & - & - & - & 02 & 02 & 03 \\
Georgia & - & - & - & - & 03 & - & - & - \\
\hline
\end{tabular}

Source: Military Balance, IISS, London, 2001-2008, cited in Anant, 2011: 2. 


\section{Key dimensions and developments}

\subsection{The links between fragility, legitimacy and non-state armed groups}

The OECD's INCAF defines a fragile state as having a "weak capacity to carry out basic functions of governing a population and its territory, and lacking the ability to develop mutually constructive and reinforcing relations with society" (OECD-DAC, 2010: 21). The World Bank, in its 2011 World Development Report focusing on conflict and security, defines fragility as "periods when states or institutions lack the capacity, accountability, or legitimacy to mediate relations between citizen groups and between citizens and the state, making them vulnerable to violence" (World Bank, 2011). Both definitions emphasise the link between state capacity and legitimacy. This is consistent with the OECD's own emphasis on the state-society link as critical for effective statebuilding. State legitimacy - both domestic and external - is a necessary condition for stability (Brinkerhoff, 2007). Legitimacy tends to be dependent on the establishment of a social contract binding the state and the civil society.

The OECD/DAC definition of the "social contract" in the context of fragility and statebuilding underlines interactions among three elements: (1) expectations that a given society has of a given state; (2) the state capacity to provide services, including security, revenue generation and control of territory to provide these services; and (3) the presence of a political elite that manages state resources and has the capacity to fulfil social expectations (OECD, 2008). When these conditions underpinning the social contract are wanting, the chance of non-state groups challenging the state becomes more likely. The non-state challenge can range from non-violent protest that expresses itself as new forms of political competition, to more violent forms of separatist civil strife that can rally for both domestic and international support. The objective of this "contention" and "contest" may be regime change or - for a people sharing a nationalist vision, or wanting to escape from socio-economic and political marginalisation within a particular political set up - it may be separate statehood (Müller, 2012). Approached from this angle, civil wars can be viewed as a project in competitive statebuilding. They may include competition for the provision of public services in the governance arena, such as protection, security, justice, education, health, food, employment and representation. In some FCAS, by delivering public goods, NSAGs can shape the social contract and take the role of the state. For instance, NSAGs such as the Sudan People's Liberation Army (SPLA), the Liberation Tigers of Tamil Eelam (LTTE) and the Moro Islamic Liberation Front (MILF), have (or had) established quasi-states or states within states in areas under their control. In SPLA-controlled or former LTTE-controlled territory a "visa" was even required for travel.

\subsection{The factors which contribute to NSAG formation}

\section{National factors}

International engagement with NSAGs often involves a profiling of the motivations and support for such groups. The pattern of recruitment and mobilisation of resources, leadership styles, military effectiveness, as well as other organisational factors, can all help identify the reasons for the popular legitimacy of these groups. The reasons for recruitment and mobilisation of civilian support involve a range of "push" and "pull" factors. These can include structural violence, environment, coercion, poverty, education and employment, family and friends, politics and ideology, culture and tradition and radicalisation (Box 2.1). Determining factors may include the nature of the conflict (high or low intensity, cross-border or internal), the pattern and nature of recruitment (seeking food, security, or employment; seeking revenge; being encouraged by family or community; or forced abduction), as well as formative, individual experiences (being involved in active fighting, sexual exploitation and abuse, or affirming their role). 


\section{Box 2.1 Radicalisation in fragile states}

Radicalisation processes are much debated, particularly in the context of terrorism. Sageman (2004; 2008) emphasises the informal and loose-knit network aspect of the global jihadi movement since the destruction of al-Qaeda's sanctuary in Afghanistan. The US National Intelligence Council's 2020 Project, Mapping the Global Future, has reported a strong incidence of youth recruitment in Arab states and the growing radicalisation of this demographic group. Low levels of education as well as stunted access to socio-economic improvement have exacerbated this phenomenon in fragile states such as Pakistan. Group socialisation can be a powerful mechanism for changing the identities of young people into soldiers. Transformation of youth through indoctrination or in group practices that involve exposure to high levels of violence and radicalising experiences of conflict and fragility can have a negative impact on civilian lives and on social reconciliation in the post-war period. These experiences also have important consequences for mental and physical wellbeing, involving the loss of education, a lack of employable skills and the destruction of a stable family life (Özerdem and Podder, 2011).

\section{Global factors}

The role of diaspora communities in violent conflicts has received keen attention in recent literature on conflict financing (Smith and Stares, 2007; Collier and Hoeffler, 2004; Shain, 2002). Diasporas can provide both economic resources and political lobbying support through international peace workers and advocacy groups that shape global opinion on peace and reconstruction efforts. Sri Lanka, Palestine, South Africa, Eritrea and Northern Ireland stand out as prominent cases of diaspora support for rebel group organisation during conflict and during peace negotiations (Orjuela, 2008). Diasporas are observed to be critical in the functioning of informal remittance networks. For instance, the Hawala system used in Somalia and Afghanistan involves little or no paperwork, lacks regulatory control, and relies mainly on personal contacts resident overseas (Makarenko, 2004).

As a result of liberalisation of trade and financial markets, terrorist finances in particular are hidden in legitimate and illegitimate businesses and disguised as commodities and cash. Certain forms of Islamic aid, small financial transfers, under-regulated Islamic banking networks and informal transfer systems have been traditional sources of funding for Al Qaeda and similar outfits (Basile, 2004). Terrorists have relied on a wide spectrum of illicit activities including narcotics trade, taxation of businesses, money laundering and credit fraud (Abuza, 2003; Billingslea, 2004; Makarenko, 2004). Groups such as the Al Qaeda, and Hezbollah have been reported to make a large percentage of their operational income from trade in narcotics (Levitt, 2002; Roth and Sever, 2007). Hamas, the Revolutionary Armed Forces of Colombia (FARC), the United Self-Defense Forces of Colombia (AUC), the Abu Sayyaf Group (ASG), the Moro Islamic Liberation Front (MILF), and the Jemaah Islamiyah (JI) are reported to have used crime and taxation of businesses to fund their operations (Sanderson, 2004; Croissant and Barlow, 2007; Roth and Sever, 2007).

Growing use of the information technology and global communications that underlie globalisation has also created easier access to new resources such as social media (internet, blogs, twitter, Youtube and social networking sites like Facebook) for NSAGs. Several rebel groups such as the Hezbollah, Hamas, the MILF, and the former LTTE among others have dedicated websites. During the Arab Spring, antigovernment protesters and opposition groups used social media networks. In Syria, for instance, despite the government's ban on the media, the Free Syria movement has relied on social media portals like YouTube, Facebook and Twitter to share developments with the world thereby shaping international policy responses. 


\subsection{The key dimensions of NSAGs: A typology}

As the above section suggests, the factors behind the formation of NSAGs are complex. Here we propose a basic typology for understanding their key dimensions (Table 2.1).

Table 2.1 A typology for understanding NSAGs

\begin{tabular}{|c|c|c|c|c|}
\hline $\begin{array}{c}\text { Core support base } \\
\text { (mobilisation dynamics) }\end{array}$ & $\begin{array}{c}\text { Domestic } \\
\text { legitimacy }\end{array}$ & $\begin{array}{c}\text { International } \\
\text { legitimacy }\end{array}$ & $\begin{array}{c}\text { Relations with } \\
\text { civilians }\end{array}$ & Resource base \\
\hline Ethnic/tribal & High & High & $\begin{array}{c}\text { Abusive/ } \\
\text { conflicting }\end{array}$ & $\begin{array}{c}\text { Community taxation } \\
\text { and support }\end{array}$ \\
\hline $\begin{array}{c}\text { Ideological/ } \\
\text { religious }\end{array}$ & Low & Low & $\begin{array}{c}\text { Protective/ } \\
\text { co-operative }\end{array}$ & $\begin{array}{c}\text { Capital based } \\
\text { exchange systems }\end{array}$ \\
\hline
\end{tabular}

This typology clusters NSAGs by identifying their core support base (ethnic/tribal or ideological/religious, but excluding diaspora support) to understand the extent of transnational linkages. This is followed by identification of levels of domestic and international legitimacy (high or low); relations with civilians (abusive or protective) that can affect post conflict peace and statebuilding, especially issues of reconciliation. Finally, the nature of the resource base can help inform funding sources (community vs. capitalist). Groups can be more dependent on community for resources or on capital based exchange systems such as natural resources, and transnational organised crime. Following from such a typology, groups such as Al Qaeda can be clustered as transnational and capital-based. Community based and protective groups are likely to enjoy stronger social and political legitimacy in the post war period compared to capitalist and abusive groups. Identification of these defining characteristics can help design policy approaches towards NSAGs in peace and statebuilding. 


\section{The impact of NSAGs on conflict and fragility}

The impact of NSAGs on conflict and fragility is multi-dimensional. While there is compelling evidence of the negative impacts that NSAGs can have for conflict and fragility, the analysis is less thorough of the positive contributions NSAGs might make to providing legitimacy and to strengthening the state-society link in FCAS. This section will concentrate on the negative impacts on peace and statebuilding in FCAS and the factors that produce, exacerbate and complicate these negative impacts. It will, however, also examine potential for positive partnership with NSAGs in rebuilding FCAS.

\subsection{Impact on human security and reconciliation}

\section{Human security}

The primary negative impact of NSAGs is on human security. ${ }^{1}$ Recent figures on the civilian death toll from civil wars since 1945 suggest an estimated 16 million people have been killed - "more than five times as many people as have died in interstate wars" (Weinstein, 2007: 4-5). Other than the loss of life, human security can involve coercive recruitment, indoctrination, abuse (Box 3.1), forced displacement and loss of property. More generally, conflict and displacement result in the loss of "human capacity" within the community; they undermine both physical and mental health of community members and deplete the skills and knowledge pool of people, which results in a degraded "social ecology" and weakened "social capital" (Lorentzen and Turpin, 1998). The impact on human security can be mitigated through international efforts to establish stronger civilian protection mechanisms in FCAS. Much of the humanitarian and developmental policy on engaging with NSAGs flows from this dimension.

\section{Societal reconciliation}

The second negative impact of NSAGs is on societal reconciliation in FCAS. Return and reconciliation processes are a key to positive peacebuilding. NSAGs may take either a protective or a predatory approach to civilian populations (Table 2.1), which will in turn affect societal reconciliation and peacebuilding in the post-conflict period. Wartime rebel-civilian relations can have a significant impact on the return and reintegration of ex-combatants and the overall quality of societal reconciliation. Poor reconciliation or unresolved tensions can give rise to complex localised conflicts. This lack of attention to the relationship and linkages between wartime recruitment patterns and post-war reintegration and reconciliation issues has been highlighted of late (Sriram and Herman, 2009; Podder, 2012). The World Bank's World Development Report (2011) has raised concerns about how few countries are truly "postconflict", given the high rates of conflict relapse. The report suggests that every civil war that began since 2003 was in a country that had a previous civil war (World Bank, 2011: 3). Even countries where peace agreements have been successfully negotiated with NSAGs - such as El Salvador, Guatamala and South Africa - continue to suffer from cycles of violence and crime, which suggests that the role of NSAGs is insufficiently understood and requires more research.

Ex-combatant or former terrorist presence and involvement in the community demonstrates social acceptance. It can help in repairing damaged vertical/horizontal social capital and often helps regenerate trust. Social reconciliation, however, is a long and arduous process that cannot be forced or externally generated. Hence NSAGs and those who are part of these groups can influence the nature of statesociety relations significantly. There is, however, growing evidence that when rebel groups transition into political parties or an elected government, they integrate core features of rebel governance into their official administrative structures. Former rebel groups in power use extra-constitutional methods of

\footnotetext{
${ }^{1}$ The term "human security" represents an effort to re-conceptualise security in a fundamental manner. It is primarily an analytical tool that focuses on ensuring security for the individual not the state.
} 
governing based on mobilisation or indoctrination. They can use their war credentials to legitimise themselves and "delegitimise" others in a competition for power and state resources (Kriger, 2006). Other studies, such as of ex-combatants in South Africa (Gear, 2002), draw attention to how ex-combatants experience stigmatisation and stereotyping in their post-military lives. These experiences make it increasingly difficult for ex-combatants to successfully reintegrate into the community -further exacerbated by the feelings of betrayal they often face.

\section{Box 3.1 Understanding why rebels abuse civilians}

Several authors offer important analytical models for interpreting rebel propensity towards civilian abuse:

1) Zahar (2000) elaborates two dimensions of identification and control in her typology of relations between communities and combatants. She argues that when a militia identifies with a population it will treat civilians well. Where no such identification exists between the militia and civilians, the modus operandi will be control.

2) Reno's (2000) dual model of rebel behaviour (predatory vs. protective) suggests that rebel groups that draw on pre-war, capital-based patronage networks function as predators. In these neopatrimonial networks, such as are found in several African and Asian countries, the resources of the state are diverted away from social welfare (Chabal and Daloz, 1999; Reno, 2000) and instead hoarded for private use and for rewarding clients in return for their political support. Hence state weakness and powerful informal networks, which Reno calls "shadow" states, are often interrelated. Leaders from communities that were marginal to dominant networks, on the other hand, tend to organise armed groups that protect local communities. Protective armed groups control their fighters through shared membership in the social institutions of a particular ethnic or religious community, and draw on local and ethnically-homogenous pools. Higher levels of civilian abuse are predicted to be more likely in cases of foreign mercenary presence (Reno, 2006).

3) Metelits (2010) suggests that insurgent behaviour towards civilians can shift from violence to nonviolence depending on the intensity of contest/rivalry with other armed groups (state or non-state) for popular legitimacy and support. Levels of violence (in this model) can be interpreted as signalling commitment or non-commitment to peace processes.

\subsection{Influencing conflict elsewhere}

\section{Regional impacts}

However, civil conflicts tend to operate within a regional and international context. Cross-border linkages or involvement of other governments and non-state actors (armed and unarmed) can have both positive and negative impacts, and be both co-operative and conflictual. Increasingly there is acknowledgement of the "bad neighbourhood" phenomenon. Sharing borders with FCAS can result in the spillover of refugees or rebel groups, or encourage illicit trade in arms, minerals, narcotics leading to regional conflict systems such as in West Africa and the African Great Lakes region (Fakuda-Parr, 2007; and see Box 3.2). The global liberal financial architecture creates transnational aid flows and offers transboundary opportunities for NSAGs to mobilise support and access resources (both material and non-material including intelligence, ideological, technological), that can also influence the strategic behaviour of armed groups elsewhere. 


\section{Box 3.2 Transnational spillovers}

Porous borders constitute an important transnational dimension of the impact of NSAG. Examples include sanctuaries for the Kurdish Workers Party (PKK) in Iraq and post-genocide instability in Central Africa following Rwanda-backed interventions against Mobutu Sese Seko (for his support to Rwandan militants) and Laurent Kabila (who switched support to Hutu insurgents). In Myanmar, the Karen rebels have sought refuge in Thailand. In Afghanistan, both the Taliban and Al Qaeda operate from sanctuaries in Pakistan's tribal areas. In the Sudanese region of Darfur, rebels have operated from eastern Chad (on account of ethnic ties). This phenomenon of transnational rebels has a historical basis, such as with the Contras in Nicaragua, the Palestinian Liberation Organisation (PLO) in the West Asian crisis, and the LTTE in Sri Lanka. Transnational support involving men, money and weapons has resulted in regional subsystems of conflict, such as in West Africa (Salehyan, 2009). In each case community support due to tribal or ethnic loyalties and recruitment drives in refugee camps have opened up transnational linkages (Achvarina and Reich, 2006).

\section{Global impacts}

Bruderlein et al. (2007) identify three linkages in a web of cause and effect that contribute to the negative impact of NSAGs on peace and statebuilding:

1) the fragmentation of conflict-afflicted states;

2) privatisation of warfare; and

3) the globalisation of political and security agendas.

State fragmentation can result from inter-group competition over resources or the result of political competition between different ethnic and tribal entities. This fragmentation process may be internal or externally-triggered through regional inter-state competition or through transnational support such as diaspora groups, migrants, refugees and criminal organisations. State weakness and powerful informal networks are often inter-related. This phenomenon gives rise to "shadow states" rather than weak states (Reno, 2000).

The emergence of private security companies (PSCs) and private military contractors (PMCs) that offer a range of security related services for both domestic and international actors in FCAS such as Afghanistan, the Balkans, Iraq, Colombia and Sudan has created a global industry in non-state forms of security provision. Governments may choose to fight NSAGs by using PSCs and PMCs as proxies. The convenient practice of "outsourcing" conflict to such agencies has intensified the weakness of governments in FCAS.

The development of weapons of mass destruction (WMD) (chemical, biological and nuclear) and the 9/11 attacks have shifted the dominant political and security paradigm from national security to fighting global terrorism. There is a growing inter-connectedness between domestic security policy formulation and international security discourses on counter-terrorism and WMD proliferation. This has meant more military intervention, backed up by private security contractors, in FCAS. The significant increase in the ease and volume of movement of human and material resources, which are central to globalisation and economic liberalisation in international trade and finance, can unleash negative forces that Heine and Thakur (2011) call "uncivil society". Disruptive factors that feed conflict cycles are increasingly "transnationalised" or "globalised" in so far as they remain beyond the effective control of the nation state. Given that non-state armed actors function within this transnationalised context, their organisational structure, financing and patterns of mobilisation are necessarily inter-linked with other global forms of insecurity. For instance, political movements obtain financing from criminal activities, as in the DRC and 
Northern Ireland. Criminal gangs can support political violence during electoral periods, as in Jamaica and Kenya. International ideological movements make common cause with local grievances, as in Afghanistan and Pakistan (World Bank, 2011). By the same mechanisms, local grievances can have a global impact. A recent study of 18 Western European countries revealed that with 60 transnational terrorist incidents per million people the economic growth rate of any country (within the study) would be reduced by 0.4 of a percentage point in a given year (Gaibulloev and Sandler, 2008).

\subsection{Potential positive impacts: popular support, legitimacy and governance}

The potential positive effect of NSAGs and the popular legitimacy that NSAGs enjoy in fragile states is a complex issue. The immediate, medium and long-term impacts all need to be analysed. In the short term, NSAG mobilisation processes that secure popular support during conflict can become the basis for postconflict legitimacy. Mobilisation may include appeals based on religion, identity and ideology issues. Civilian recruits may be "socialised" into their combatant roles through participation in ritualistic practices of induction or through proof of loyalty for the group. This can include cultural dimensions of creating a soldier identity and enhancing cohesion. In case of groups that rely on civilians and are protective towards them, cultural issues relating to ethnic identity, religious belief or traditional forms of justice and law can become strong basis for civilian loyalty and support. These practices later offer effective basis for social legitimacy of a particular NSAG, sources that can be harnessed for "bottom-up" statebuilding. In the case of the Eritrean People's Liberation Front (EPLF) in Eritrea, the state consolidation process has been traced to rebel government's structures during the conflict years. Similarly, the SPLA in South Sudan tried to establish a nascent civil administration in areas under its control before the Comprehensive Peace Agreement (CPA) was negotiated. Although it suffered from a lack of a merit-based recruitment system, and was open to financial abuse due to missing audit and budgeting procedures, it demonstrated the group's commitment to statebuilding.

However, group loyalty often implies exclusivity. NSAGs exhibit a strong ethnic or religious basis by drawing on the pre-conflict history of socio-economic marginalisation or exclusion from state power. This can have implications for the extent or inclusiveness of their governance and service delivery towards civilian communities. For instance, local and national elections in Burundi in 2005 saw the former rebel group the National Council for the Defense of Democracy/Forces for the Defense of Democracy (CNDD/FDD) fare well. However, the ensuing decentralisation of governance systems has replicated elite control over a vertical system, thereby undermining civilian hopes for change following the civil war. In other words, governance structures that predate war and that might have short-term benefits may also have negative implications in the long term. Over the longer term, positive impacts may be dissipated if the victory of a rebel opposition group does not change the weaknesses of the "system" of governance that predates conflict. If the system preserves its corrupt, nepotistic and clientelist features, it will negate any short-term positive impacts of civilian protection during conflict in rebel-controlled areas (Uvin, 2008).

This preliminary analysis helps to contextualise the complex and multifaceted role that NSAGs play in peace and statebuilding, one that has both positive and negative implications. The paper will develop these issues further in the following sections. Some of the key legal and policy developments in international engagement with NSAGs are discussed next. 


\section{Is the international response helping or hindering fragile states?}

International engagement and policy response towards NSAGs have evolved considerably in the past two decades. However, while there has been increasing acknowledgement of the need to engage with NSAGs, a state-centric legal framework has meant that until recently there has been little actual international engagement. This section focuses on two key dimensions that have determined the nature of the international community's responses to NSAGs and shaped the framework for engagement with them: (1) the legal framework; and (2) the international policy framework.

\subsection{Legal framework}

This section looks at several elements of the legal framework:

- The legal implications of the need to engage with armed groups in the peaceful settlement of conflicts.

- The need to apply humanitarian and human rights legal norms equally to both state and non-state armed violence.

- The need to improve the diffusion of and general adherence to international human rights norms among NSAGs.

- The complicating influence of counter-terrorism laws.

\section{Engaging with NSAGs within a legal framework}

An important element in peace mediation work for the past two decades has been learning how to talk or deal with armed groups. Traditionally, however, a key difficulty in engaging with non-state armed groups is that they lack a legal "personality" and therefore official recognition within the main legal and normative frameworks governing the use of force. International engagement with NSAGs within the framework of a legally-binding agreement is increasingly viewed as central to the planning of humanitarian and development assistance in conflict-affected areas (Hofmann and Schneckener, 2011). The United Nations Security Council (UNSC) has also recognised the importance of granting parallel and legitimate roles to non-state actors, such as rebel forces and militias, in peace agreements (UNSC, 2007). This reflects an increased focus within the United Nations on mediation and the need to engage with armed groups in the peaceful settlement of conflicts. For example there was a General Assembly resolution on mediation made in June $2011 .{ }^{1}$ The UN has been in direct discussion with militias in Somalia on multiple levels, including military, diplomatic and economic negotiations (Krahmann, 2005; Vinci, 2009; Mulaj, 2010). The German Development Agency (GTZ) has also worked through local warlords such as Mohammed Daoud Daud in Kunduz province for ensuring safe access and movement of its personnel. These forms of engagement have become critical for ensuring the safety of humanitarian and diplomatic workers who can become victims or targets of terrorism and insurgency. 


\section{Applying humanitarian and human rights legal norms equally to both state and non-state armed}

violence

International humanitarian and human rights law is primarily binding on and applicable to states. International agreements such as the 2000 Optional Protocol to the Convention on the Rights of the Child (OP-CRC) and the Additional Protocol II of the Geneva Conventions (1977) constitute the main legal instruments in this respect (Holmquist, 2005). There is growing recognition of the need to apply legal norms equally to both state and non-state armed violence. The indictment and trial of rebel leaders for war crimes and crimes against humanity at the International Criminal Court (ICC) has resulted in stronger checks on the behaviour of NSAGs in FCAS (Sriram, 2008). War crimes trials such as the recent Charles Taylor indictment by the ICC send out powerful messages to other NSAGs and have become a prominent development in how the international community has engaged with NSAGs. These issues provide the overarching framework for international policy responses to terrorism and statebuilding efforts.

\section{Monitoring and building awareness of human rights}

Within this context, international monitoring of human rights has evolved as a critical element for promoting compliance with international humanitarian and human rights norms. All parties involved in conflict require impartial monitoring and verification, which may include (Geneva Academy of International Humanitarian Law and Human Rights, 2010):

- reporting by NSAGs on their own compliance with norms;

- verification missions by third parties (involving local and/or international actors);

- national human rights commissions;

- confidential monitoring and reporting on the behaviour of NSAGs; and

- "naming and shaming" of violations and violators.

Using a mix of these tools, humanitarian and development workers in the field have tried to plug gaps in international humanitarian and human rights laws and discourage negative tactics (civilian deaths, sexual violence, torture, genocide, plunder and forced displacement) commonly used by NSAGs during conflict and peacebuilding processes. Over the last decade, international non-governmental organisations (INGOs) have developed a wide range of strategies to improve the diffusion of and general adherence to international human rights norms among these groups. The aim has been to adapt their behaviour by offering them training in international humanitarian law - this is a routine feature of International Committee of the Red Cross (ICRC) missions the world over. INGOs like Geneva Call and the Coalition to Stop the Use of Child Soldiers (CSUCS) have also undertaken robust advocacy measures. Geneva Call, for instance, has drawn up a "deed of commitment" to secure compliance from NSAGs on not using antipersonnel landmines. Flowing from the work of CSUCS, the Office of the Special Representative of the UN Secretary General on Children and Armed Conflict has also negotiated compliance compacts with several NSAGs to stop the recruitment of minors.

In May 2009, the UN Secretary General's report on the protection of civilians identified NSAGs' compliance with international humanitarian law and human rights standards as one of the five core challenges for more effective civilian protection (UN, 2009). 
Since the attacks on the World Trade Centre on September 11 2001, international counter-terrorism laws have also informed the legal framework governing engagement with NSAGs. Thirteen international conventions address the issue of terrorism and list specific terrorist acts although there is to date no internationally-agreed definition of a terrorist (Tams, 2009). Various UN Security Council Resolutions (UNSCR) require states to take steps against NSAGs, including criminalising terrorism and imposing sanctions on armed groups in specific conflicts. ${ }^{2}$ UN member states both enforce those resolutions and add the resulting lists of groups / individuals that are referred to as terrorists to their own national law enforcement procedures. Terrorist lists have resulted in targeted sanctions such as travel bans, asset freezes and arms embargoes against proscribed groups and individuals. National lists are usually more transparent about procedures and criteria. States such as Australia, Canada, the United Kingdom and the United States maintain terrorist lists that are generally embedded in national legislation and involve punishment through criminalisation, although procedures and lists vary from country to country. These governments tend to provide little information on how groups and individuals can get themselves de-listed. The de-listing processes associated with UNSCR 1267 in particular have proven slow and lack transparency. ${ }^{3}$

As a result, two countervailing sets of norms - one promoting humanitarian engagement with NSAGs in armed conflict in order to protect populations in need, and the other prohibiting such engagement with listed "terrorist" groups in order to protect domestic security - define the international legal engagement with NSAGs in FCAS. ${ }^{4}$ Anti-terrorist legislation complicates international engagement with NSAGs in several ways. Firstly, it may result in a conservative bias in favour of the sitting government due to terrorist listing of NSAGs. Secondly, it may disregard the domestic legitimacy that NSAGs may have. Thirdly, it can overlook state weakness or failure in providing public security and good governance

\subsection{The policy framework}

This section summarises the major international policy framework guiding engagement with NSAGs under three broad headings: (1) The war on terrorism and the securitisation of aid; (2) statebuilding policies; (3) approaches to peace settlements and managing "spoilers"; (4) aid policies and distortions and (5) disarmament, demobilisation and reintegration.

\section{The war on terrorism and the securitisation of aid}

The events of $9 / 11$ evoked a primarily military reaction that became known as the global war on terror (GWOT). ${ }^{5}$ The objectives of this military campaign are three-pronged: free the world of Islamic terrorism, remove all $A$ l Qaeda related operatives in Afghanistan and end state-sponsored terrorism. This military response has intensified conflicts in Afghanistan, Pakistan, Iraq and now the Middle East. Participation in the US-led military campaign in Afghanistan by NATO and non-NATO countries such as Bangladesh, China, Germany, France, UK, Greece, Cyprus, Egypt, India, Japan, Kuwait, Kyrgyzstan, Malaysia, Pakistan, Russia, Tajikistan, Turkmenistan, United Arab Emirates (UAE) and Uzbekistan has resulted in a Cold War-type polarisation between states fighting terrorism and groups listed as terrorists or states identified as sponsors of terrorism. This has resulted in an increased threat of Islamic terrorism against countries that allied with the US in its anti-terror campaign.

Apart from this system-wide ramification of a specific politico-military policy stance adopted by the US, the GWOT has witnessed the forging of new partnerships in the areas of intelligence sharing, and counterterrorism aid (Biersteker and Eckert, 2007). US intelligence sharing alliances can be grouped into two categories as well; on the one hand, traditional allies, such as Canada, the UK, Australia and NATO members; on the other hand, new allies or renewed relationships with non-traditional friends cultivated for the GWOT, such as Pakistan, Yemen and Uzbekistan, Saudi Arabia and Jordan (Reveron, 2006). 
Countries such as Iran, Iraq, Syria and Sudan were listed by the US as state sponsors of terrorism and became targets of military and non-military sanctions that added to their internal fragility.

Fleck and Kilby (2010) suggest that US post-9/11 flows of bilateral aid are based less on recipient needs, and more on strategic priorities. As a result, increased assistance has been directed towards countries that are frontline states in the fight against terrorism (Box 4.1). Large bilateral aid flows to Afghanistan, Iraq, Pakistan, Yemen, and Sudan is evidence of this trend (Ali, 2010). In 2010/11, US aid to Yemen was close to USD100 million, with a USD10 billion aggregate commitment for Afghanistan, Iraq, and Pakistan (Hill, 2010). In this paper, counter-terrorism aid refers to "aid that a donor gives to a foreign country aimed at bolstering its counterterrorism efforts against a resident transnational terrorist group". Thus in order to improve surveillance and information gathering, the US has disbursed unprecedented amounts of both material and non-material resources.

While counter-terrorism aid does not stand apart from the long history of US foreign policy initiatives such as Cold War related military assistance, the sheer amount of resources made available, as well as the new relationships or political alliances that have been forged to combat terrorism, impart a new dimension.

The proscription of armed groups as terrorists under either national or international legislation has made international engagement with them complex. For instance, most UN staff and agencies are required to operate within the law of the country where they are deployed. The use of UNSCR 1373 for labelling internal opposition groups as terrorist organisations has become widespread (see above); this prohibits UN staff from considering talking to or engaging with these groups. In June 2010 the US Supreme Court stated that the United States government has asserted global extraterritorial jurisdiction, claiming the right to prosecute engagement with armed groups even if it was for conflict-resolution purposes. ${ }^{6}$

Furthermore, there is growing evidence of the negative impact that counter-terrorism aid may have on conflict and fragility. Recent studies suggest that the recipient country's regime stability may become dependent in part on counter-terrorism aid (Bandyopadhyay et al., 2009; Azam and Delacroix, 2006; Azam and Thelen, 2008; 2010). This dependence can result in the political leadership losing popular support and becoming more fragile. There is evidence of this occurring in Pakistan, Yemen, and Iraq. In each country, fractionalisation between competing political elites and ethnic constituencies created new non-state armed configurations that intensified competition for limited resources, thereby exacerbating both conflict and fragility. Besides, giving financial support to friendly regimes in the war against terrorism entails greater risks of a terrorist backlash against the donor should those regimes fall. Therefore, although there is a real desire to incentivise political leadership in source countries of terrorism to reduce the supply of terrorists, counter-terrorism policies are not always implemented.

Osama Bin Laden's death in May 2011 in Abbottabad near the Pakistani capital has put the GWOTrelated alliances under greater scrutiny. Counter-terrorism aid to Pakistan has been redirected to NSAGs that operate with state compliance in the Af-Pak region. The Haqqani network in Afghanistan - implicated in the terrorist attack on the American Embassy in Kabul - has also reportedly received support from the Pakistan intelligence agency (ISI) (Quinlan, 2012). While the nature and extent of the effects that counterterrorism aid may have on conflict and fragility remain a matter of conjecture rather than of empirical evidence, there is growing indication that awareness of these negative impacts must be mainstreamed into international policy responses to NSAGs in FCAS.

There is growing concern among humanitarian and development specialists about the increasing international policy focus on counter-terrorism. This focus has been viewed as a negative securitisation of aid, which is progressively encroaching on humanitarian space (Bradbury and Kleinmann, 2010). In 2009, USD 50 million as part of Overseas Foreign Assistance (OFA) and USAID assistance for Somalia was suspended due to concerns that it would benefit the main Islamic militant group, Al Shabaab (but see Box 4.1). 


\section{Box 4.1 Being more nuanced in humanitarian work with NSAGs: the case of Somalia}

In a recent conference sponsored by the Overseas Development Institute (ODI), the Humanitarian Policy Group and the School of Oriental and African Studies (SOAS at the University of London), the securitisation of aid in Somalia was identified as a major challenge hindering effective humanitarian work. The conference criticised the limited political analysis that governs humanitarian engagement with NSAGs such as Al Shabaab. It can result in promoting stereotypes through the application of counterterrorism approaches that may be unrelated to reality. There is growing evidence that it may be useful to invoke local contextual norms, to understand the genesis of NSAGs and to engage with actors outside the formal humanitarian sector, such as members of local communities, the diaspora or the private sector, as more effective interlocutors with such groups. For instance if $A$ l Shabaab is viewed as a social movement that is more amenable to the dictates of Quranic law than to the Geneva Conventions, it will result in a radical change in international policy outlook on engagement with this group (ODI/HPG/SOAS, 2011).

Within this post $9 / 11$, anti-terrorist context NSAGs have come to be viewed as peace spoilers or terrorists and as a source of challenge for established socio-political orders (Dudouet et al., 2012). This negative perception does not question the nature of the state - whether it is predatory or repressive; nor does it examine the true nature of NSAGs - their degree of social legitimacy, political roles and aspirations. As a result, terrorist listing and proscription regimes can have several unintended negative consequences: (1) constraining engagement with proscribed NSAGs, thereby obstructing inclusion of such groups in a political settlement; and (2) encouraging radical behaviour over moderation and constructive dialogue.

\section{Statebuilding policies: moving beyond the state}

Statebuilding is based on a set of Western liberal values, institutions and norms that increasingly acknowledge the need to adjust to local realities (Scott, 2007; OECD, 2010; Box 4.2). International policy on statebuilding is enumerated in several documents that reflect international consultation and debate on aid effectiveness, reconstruction and capacity development. These include the Cairo Conference on Capacity Development (February 2011), the Addis Ababa Meeting on Peacebuilding and Statebuilding (September 2011) and the G7+ Juba Ministerial Retreat (October 2011) among others. The International Dialogue on Peacebuilding and Statebuilding has crafted a "New Deal" for engagement in fragile states (IDPS, 2011). This framework proposes five key peacebuilding and statebuilding goals - legitimate polities, security, justice, economic foundations, revenue and services. Through its focus on country-led, "owned" and inclusive ways of engaging, it seeks to encourage harmonisation and donor co-ordination and enhance transparency both by the donor and the beneficiary. Liberal peace and development efforts have ranged from the construction of new governing institutions (Timor-Leste), the reform of existing states away from authoritarian models (South Africa) and international recognition of new states (Kosovo) (Mac Ginty, 2011). The focus of international engagement as evidenced through this history is largely state-centric, with particular focus on institutions and an elected executive.

However, this focus is out of sync with field-level realities that offer rich evidence of the important roles that non-state actors, including armed group leaders, play in implementing statebuilding projects at the local level. Customary chiefs have helped resolve or prevent civil and criminal cases in several African post-conflict societies. In Liberia, alternative dispute resolution in rural areas has been a significant success, particularly vis-à-vis land disputes, and in the work of the Land Reform Commission. ${ }^{7}$ The role of community-based security groups has also been acknowledged as positive for international statebuilding thereby marking a shift from state-centric institutional capacity development to more indigenous and effective solutions (Baker, 2010). Despite efforts to engage non-state security and justice actors in reconstruction and statebuilding interventions (OECD, 2010; World Bank, 2011) their role continues to be insufficiently mainstreamed in practice. 


\section{Box 4.2. What is statebuilding?}

Statebuilding tends to be premised on the development of legitimate institutions of government (Paris and Sisk, 2009). However, the OECD-DAC guidelines, Supporting Statebuilding in Situations of Conflict and Fragility, emphasise the importance of looking beyond creating institutions to reconstructing the state-society relations, state legitimacy and the political and social fabric of society (OECD, 2011a). The focus here is on the relational functions of state and society institutions in the arena of security - both public and private. However the state-society interface in contexts of weak institutions and competing conflict actors is complex. It has important implications for international engagement with NSAGs in FCAS.

The Research Partnership on Post-war Statebuilding (RPPS) project emphasises five key tensions that complicate statebuilding in fragile contexts: (1) the use of outside intervention to foster self-governments; (2) defining "legitimate" local leaders; (3) the use of liberal democracy; (4) encouraging a new start while reaffirming history; and (5) leveraging short-term imperatives before prioritising longer-term objectives (Paris and Sisk, 2007). These tensions shape policy dilemmas towards NSAGs in multiple ways. Greater NSAG inclusion and local participation in reconstruction efforts encourage a lighter footprint for external involvement. If a peace settlement mandates a transitional government that offers interim stability before an elected government can come to power, leaders from various rebel groups may seek inclusion in these transitional arrangements. Without appropriate representation of stakeholders, the peacebuilding effort would face resistance and encourage spoiling behaviour.

Elite bargaining for international resources and substitution of international expertise in place of local capacity development can lengthen international presence. Donor competition for supporting key areas such as reform of security, justice and economic sectors and discrepancy between resource commitment and disbursement or tying aid to conditions can further exacerbate coherence dilemmas. Further, the conflict between the need to reaffirm history and the need for a clean start (in case pre-war inequalities persist, or patron-client relations continue in the post-war period) can undermine efforts at reforming governance, justice, rule of law and security sectors. NSAGs can offer parallel or informal networks and forms of security as well as justice. This complexity and lack of state monopoly can exacerbate gaps in both capacity and legitimacy. As a result dependency on external actors and duration of their engagement can be prolonged.

Co-operative and fruitful relations between local leadership and international policy makers can help overcome policy dilemmas in statebuilding. This entails recognition of both the positive and negative role that NSAGs can play in statebuilding. Keen (1998) has underlined that it is important to identify which groups take advantage of fragility and conflict for private purposes. In DRC, statebuilding involved an important role for NSAGs such as warlords and militias (Beswick, 2009; Eriksen, 2009). The Goma peace agreement signed in 2008 made access to statebuilding aid conditional on the establishment of a new national coalition government. Members of the government had a strong interest in preserving weakness in order to access donor funds and maintain formal positions of power. State weakness was a resource, allowing private aggrandisement and private militias ostensibly for protection in an insecure environment. In neo-patrimonial societies such as the DRC, resources of the state are used for rewarding clients in return for their political support (Clapham, 1998).

Another important lesson is highlighted in an analysis of the international community's negotiations with warlords in Somalia (Hansen, 2003). Approaches that bestow international legitimacy on NSAGs without establishing their power base and sources of traditional local legitimacy to enforce the peace are likely to falter. In Somalia, warlords have claimed strength based on the promise of protection, supremacy and spoils for their clans, and the domination of others in an order founded on social and economic division. In 
the late 1990s, the warlords lost power due to resource constraints (Hansen, 2003). Wealthy businessmen began establishing their own militias and recruited trained soldiers (who previously worked for these warlords) to secure themselves. However warlords such as Mohamed Farrah Aidid benefited economically due to his control over production of most goods and services at that time. The UN Mission in Somalia (UNOSOM II) relied upon these supplies and was economically subsidising the attacks by his forces while formally declaring him an enemy. Later the UN moved towards a decentralised and bottom-up approach that produced a parliament. However it could not prevent conflict relapse due to external interference and inclusion of the warlords in the transitional government structure (TNG) (Hansen, 2003).

South Sudan offers an important case study of NSAG involvement in "state formation". International capacity building and financial support to physical reconstruction has been significant - the EU has committed EUR 260 million for statebuilding efforts between 2011 and 2013 and the US has also pledged a similar amount every year. The UN Mission in South Sudan (UNMISS) cost three times that figure each year. These resources seek to aid the SPLM's political transition to democratic politics. In South Sudan, armed groups range from tribal self-defence militias, to proxy groups of the Sudanese Armed Forces (SAF). Despite integration into the SPLA, fragmentation remains, possibly as a hangover of the rebellion, continuing problems in Jonglei state during 2010/11. The rank and file soldiers of the SPLA remain poorly paid and undisciplined. As a result SPLM/A's transition faces important fragmentation challenges with rival groups seeking political inclusion and access to state resources. Donors continue to subsidise health and education sectors while clientelist structures in administration and security apparatus remain intact. By approaching rebuilding of formal institutions in a top-down state-focused manner, recovery efforts may be disconnected from simultaneous bottom-up civil society approaches at peacebuilding.

Another policy weakness is the use of informal security providers in statebuilding projects. This can negatively affect communities, fragment reconstruction agendas and inject significant amounts of cash into armed organisations outside of government control. In Afghanistan, the support given to progovernment militias by the US and NATO-ISAF in order to advance political and reconstruction objectives has exacerbated the predation of local communities and led to new conflicts and greater fragility. Hence, an unintended negative consequence of statebuilding has been the proliferation of non-state security actors with low accountability to governments that may be weak and fragile in the first place. The US Congress report Transforming Wartime Contracting: Controlling Costs, Reducing Risks (Commisssion on Wartime Contracting in Iraq and Afghanistan, 2011) suggests that 133610 private military contracts have been issued in Iraq and another 68199 in Afghanistan. Private firms, ministries and civilian NGOs also hire private security companies (PSCs) to provide protection and secure transit for goods and personnel. The strategic objective was to free up troops to conduct military operations against the Taliban and other insurgent groups. However, private security provision raises legitimacy challenges and may reinforce weakness or prolong dependency on external security provision. Another recent report Warlord Inc. (US House of Representatives, 2010) concludes that PSCs under the Host Nation Trucking programme were "warlords, strongmen, commanders and militia leaders". The congressional committee findings suggest that "four out of eight original prime contractors involved in Task Force 2010 were involved in reverse money laundering of at least USD360 million" (Gregory, 2012: 9).

\section{Approaches to peace settlements and managing "spoilers"}

The academic literature on the durability of peace settlements is vast (Fortna 2003; 2004; Hartzell and Hoddie, 2003; Jarstad and Nilsson, 2008; Walter, 1999). Important themes in this include a focus on spoilers (Ayres, 2006; Newman and Richmond, 2006; Stedman, 1997; Zahar, 2003; Sriram, 2008) and the credibility of NSAG commitment to peace (Walter, 1997; Kydd and Walter, 2002; Bapat, 2006: 214). Nonstate security actors - rebel group leaders, warlords, military commanders, and traditional elites can be important "spoilers" i.e. capable of thwarting peace. International policy on managing spoilers ranges from the use of inducements, co-operation, socialisation efforts to more arbitrary measures such as disregard, apolitical action, and exclusion. The approaches are many (Schneckener, 2011): 
- Realist approaches focus on elimination, suppression or control.

- Institutionalist approaches seek to change interest and policies of groups through co-option, bargaining, negotiation, third party mediation.

- Constructivist approaches concentrate on a change in norms (such as non-violence) and in selfconception (identity) of the respective actors range from persuasion and adaptation, naming and shaming to offering amnesty.

This literature on peace settlements draws from practical case study lessons and has guided the evolving policy engagement with NSAGs in FCAS. This policy ranges from facilitation and mediation to soft diplomacy tactics for opening constructive dialogue with NSAGs. Lessons learnt include the importance of neutrality, the inclusion of legitimate stakeholders and the careful use of aid resources for encouraging participation and buy in. Practitioners today favour inclusion of all rebel groups in peace settlements (Nilsson, 2008).

Also, there is growing evidence that when rebel groups transition into political parties or an elected government, their administrative structures continue to exhibit core features of rebel governance. Extraconstitutional methods of governing based on group mobilisation or indoctrination, combined with a drive by former rebel leaders to use war credentials to legitimise state ownership and "delegitimise" others in a competition for power and resources have been cited in studies on the political transition of rebel groups (Kriger, 2006). For instance in the case of the EPLF in Eritrea, the state consolidation process has been traced to rebel government's structures during the conflict years; similarly, the SPLA in South Sudan also tried to establish a nascent civil administration in areas under its control before the comprehensive peace agreement (CPA) was negotiated.

\section{Aid policies and distortions}

The capacity of NSAGs and the resources available to them has expanded exponentially as a result of peace and statebuilding activities. Patterns of aid and donor activity that increase horizontal inequality and entrench the exclusion of certain ethnic/regional groups or enhance their political oppression may increase the risks of conflict. Flowing from this, there is a growing recognition of the negative impact that international financial resources for peace and statebuilding may have on conflict and fragility.

Donor willingness to provide political and economic pay-offs for insurgents' violence is one source of negative impacts. Political settlements that offer positions in government or introduce disarmament, demobilisation and reintegration (DDR) programmes (cash, training or jobs in exchange for surrending weapons) can create incentives to use violent insurgency a bargaining tactic. Rebel leaders in the Democratic Republic of Congo (DRC), Chad, Republic of Congo (RoC) and Côte d'Ivoire had been political elites who had served in senior government positions under the Mobutu and Kabila regimes. These groups resorted to violence as a route back to political power. Similarly ex-combatants in West Africa have taken part in neighbouring conflicts to "do well" out of DDR programmes resulting in a "regional mercenary" phenomenon (Nilsson, 2008; Podder, 2010).

Rwanda (pre-1994), Afghanistan and Sierra Leone are all important examples of where development aid and humanitarian relief during, before and after conflict provided financial resources that reinforced tensions and repressive state behaviour (Andersen, 1999; Uvin, 1998). Capture of aid resources can provide incentives to NSAGs - empowering or disempowering them vis-à-vis their rivals. Development aid can also enhance conflict risks through its influence on government policy. Economic aid encourages 
external input into domestic policy-making - this interconnection between international agendas and domestic policies may influence NSAG violence (Fakuda-Parr, 2007).

The resource endowment of NSAGs can influence the relative success or failure of international efforts to engage with them (Box 4.3). This reveals the need to understand how NSAGs finance their operations, their level of dependency on civilian support vs. external funding and their amenability to a peace settlement.

\section{Box 4.3 On NSAG dynamics and aid}

The 2004 Indian Ocean Tsunami provides an interesting case for revealing the interaction between NSAGs and humanitarian aid. At the time there were two relatively similar conflicts occurring in Sri Lanka and Aceh, Indonesia. The main rebel group in the former was the Liberation Tigers of Tamil Eelam (LTTE); the latter involved the Free Aceh Movement (GAM). Each group had access to very different types of resources and support. The LTTE and the Sri Lankan government could not arrive at a compromise solution for disbursement of relief aid in the north and east regions (under LTTE control at that point). Analysts suggest that the LTTE felt threatened by relief workers gaining access to these areas. It was also less reliant on international aid support for organisational financing because it was able to tap into lucrative remittances from the overseas diaspora. It was therefore less amenable to political compromise. It also became less reliant on the local civilian population for material and non-material resources.

By contrast in Indonesia, the GAM was more aligned with the needs of the local population and heavily dependent on their support. The GAM found greater value in relief aid and was more amenable to a peace settlement.

Source: Beardsley, K. and B. McQuinn (2009), "Rebel Groups as Predatory Organizations: The Political Effects of the 2004 Tsunami in Indonesia and Sri Lanka", in Journal of Conflict Resolution, 53: 624.

On the other hand, NSAGs can be key actors, enabling humanitarian organisations to access civilian populations in FCAS. These populations, in turn, may provide resources (logistics, food and supplies) to NSAGs for sustenance and survival. In Sudan, the SPLA and the SPLM incorporated the complex operations of foreigners into their strategies for fighting and gaining political power. Through the "Operation Lifeline Sudan" (OLS) NGOs actively collaborated with the rebels, providing them with critical supplies and transport. The SPLA army indirectly benefited from US agencies that delivered aid and supplies to Sudan Relief and Rehabilitation Association (SRRA) under the OLS apparatus. Aid agencies provided public services for the local population while the SPLA acted as a gatekeeper with veto rights over OLS relief flights. The UN and other humanitarian aid agencies provided $80 \%$ of South Sudan's primary health care and safe drinking water; most of these external agencies were dependent on the rebels for accessing target populations. Another example of humanitarian aid disbursement through NSAGs was during the 2005 Kashmir earthquake near Muzaffarabad, the capital of Pakistan-controlled Kashmir. In this case, Al Qaeda militants worked closely with the US and UN humanitarian agencies in Kashmir with the backing of Pakistan - a key US ally in the global war on terror (Bhatt, 2007).

These examples highlight the complex ways in which international humanitarian aid interacts with the capacity of NSAGs. They also underline the interdependency between humanitarian actors and NSAGs. While international engagement has moved forward to encourage legal norms and best practice for balancing how NSAGs can assist in humanitarian engagement, this area still requires policy attention with regard to the positive and negative impacts of negotiating access through NSAGs.

Beardsley and McQuinn (2009) relate territorial objectives, popular support base and resource extraction mechanisms used by NSAGs to their income sources. For instance the Revolutionary United Front (RUF) 
in Sierra Leone relied on diamond mining and was openly abusive towards civilian populations, perhaps as a result of its low dependence on civilian resources. The Communist Party of Nepal (Maoist) was much more reliant on civilian support and so was less abusive towards them, although it did collect taxes from impoverished communities and local businesses. In Sri Lanka, the north east was the proto-state of a "Tamil Eelam", however reliance on diaspora remittances meant the LTTE's return on revenue income was low compared to a group like the FARC in Colombia that came to rely increasingly on narcotics sales. To understand this link, Klapdor (2009) suggests that a rebel group's ability to access resources helps in shifting itself into the arena of democratic politics. Popular support, internal cohesion of the organisation and international legitimacy are three key variables that help in this transformation process (Soderberg, 2007).

Rebel groups may transform into political parties in response to purely economic opportunities (Collier and Hoeffler, 1998; Ballentine and Sherman, 2003). However, evidence from the above cases and related literature offers important lessons for international policy engagement with NSAGs in peace and statebuilding. Firstly, it suggests that NSAGs may be correspondingly more amenable to negotiating peace settlements depending on the extent to which they have their own, self-sourced economic resources or are dependent on civilian or domestic support. Secondly, when domestic civilian support for the group is high and the leadership is confident about community-backed political legitimacy they are more likely to co-operate with international statebuilding efforts such as elections and governance reform. Statebuilding interventions can provide greater economic incentive towards transformation into legitimate political roles by offering key positions in government and access to development funding for reconstruction efforts. By addressing the role that resources play in shaping NSAGs behaviour and political will international donors can help design more effective and inclusive statebuilding interventions that enjoy co-operation and partnership from all relevant stakeholders.

\section{Disarmament, demobilisation and reintegration}

Lasting peace is often a result of successful DDR and a political transformation of rebel groups. For instance, in Angola, UNITA's reintegration has been successful largely because the rebel group transformed from a rebel movement into a leading political party. Political participation of NSAGs can encourage demilitarisation of politics (Lyons, 2005). The end result would be inclusive, democratic governance structures that are legitimate, accountable, and non-violent.

Incomplete and inadequate DDR can result in the perpetuation of sub-state power formations. For example, Ucko (2008) asserts that in Iraq the political reintegration of irregular armed groups was accorded a low priority, with the result that in the years following the US invasion the country relapsed into civil war. While this may have been only one factor amongst many in triggering relapse, the fact remains that the second wave of conflict was characterised by insurgent violence, militia rule, crime and largescale insecurity that could have been eliminated through effective disarmament strategies.

International policymakers are proactive in the arena of ex-combatant reintegration and terrorist rehabilitation efforts. These have important linkages with the overall societal reconciliation process. Postconflict terrorist rehabilitation and prevention of recidivism or further radicalisation, is premised on effective reconciliation and elements of social and economic justice. These processes range from the basic need for co-existence to the more complex stage of re-establishing trust to foster more cooperative and constructive relationships (Stovel, 2008). Institutionalisation of truth and reconciliation commissions and other mechanisms of transitional justice that can strengthen peace settlements have become increasingly popular. These truth-telling processes have both positive and negative consequences. They can encourage societal reconciliation through acceptance of wrongs, seeking forgiveness and punishing perpetrators. However, they are equally capable of excluding particular groups in society through identification and targeting. While the factors that influence the variance in outcome are contextual and 
rooted in domestic politics such as inter-ethnic or inter-group contest, in most instances transitional justice processes have encouraged inter-community dialogue (Sriram and Herman, 2009).

\subsection{Policy assessment}

From the above discussion it is evident that the international community often adopts an inconsistent approach to peace and statebuilding and to the engagement of NSAGs in these interventions. The choice of domestic alliances or regional allies to secure "political will" for peace, when premised on short-term expedience, can result in negative impacts. Such a choice may empower certain groups (tribal or ethnic) at the expense of the legitimacy and inclusiveness that are key to strong state-society relations. Such a policy response may also prove ineffective in disentangling non-state armed structures. The single sovereign approach as practised in statebuilding approaches to date does not adequately accommodate the legitimacy claims of NSAGs. Without accommodating popular interests and aspirations, statebuilding efforts could result in juridical but otherwise meaningless, non-empirical states (Beswick, 2009).

Post-conflict environments are fluid and require careful engagement, especially with NSAGs. Decisions underlying engagement, including the disbursement of humanitarian and counter-terrorism aid, must take into consideration the regional and transnational linkages of NSAGs. The main question to be debated by policymakers is how useful is statebuilding and counter-terrorism aid support? Our analysis suggests that there is a need to emphasise regional peacebuilding over statebuilding in particular countries.

In cases such as Ethiopia, Uganda, Rwanda, and Pakistan an externalisation of unresolved tensions has resulted in conflict spillover or the use of bases for cross-border strikes and terrorist violence. For instance, Uganda has succeeded in pushing out the LRA rebels into DRC, South Sudan and CAR. Rwanda has opted for a military pursuit solution towards remnant opposition groups such as FDLR that operates out of Eastern DRC. Ethiopia's role in Somalia and its on-going proxy war with Eritrea can be viewed as a failure of statebuilding of a different kind (Shepard, 2010). It is an atypical fragile state that has been embroiled in both regional and Cold War rivalry. While it has not suffered intrusive international intervention, it has received vast amounts of external resources for reconstruction and development that have aided the statebuilding process.

Our assessment of international policy responses for engaging with NSAGs as part of peace and statebuilding efforts reveals both positive and negative dimensions. This paper has attempted to highlight some of the key areas where engagement with indigenous institutions and surviving structures of governance can provide the basis for more organic, locally owned and effective statebuilding. Negative impacts of aid and reconstruction support in the areas of private security provision or inclusion of illegitimate groups in peace settlements have also been underlined. These offer an insight into some of the areas where future policy focus must be directed for more effective engagement with NSAGs in peace and statebuilding. This is the subject of the next section. 


\section{Notes}

${ }^{1}$ See (A/RES/65/283) at www.globalalct.org.

${ }^{2}$ E.g. 1267, 1988 and 1989 in relation to the Taliban and Al Qaeda; and UNSCRs 1373, 1540 and 1624.

3 See www.globalalct.org

${ }^{4}$ Ibid.

${ }^{5}$ The United States initiated three military operations: (1) Operation Enduring Freedom (OEF) covering Afghanistan and other GWOT operations ranging from the Philippines to Djibouti that began immediately after the 9/11 attacks and continue to date; (2) Operation Noble Eagle (ONE) meant to provide enhanced security for US military bases and other homeland security that was launched in response to the attacks; (3) Operation Iraqi Freedom (OIF) that began in the third quarter of 2002 with the build-up of troops for the March 2003 invasion of Iraq and continues with counter-insurgency and stability operations.

${ }^{6}$ Information from www.globalalct.org.

${ }^{7}$ Interview with Ms Chelsea Payne, Carter Centre, Monrovia (28 November 2011). 


\section{New entry points for international policy}

As is evident from the previous section, engagement with NSAGs has been incorporated into international policy and approaches to peace and statebuilding in FCAS in a number of ways. This engagement has resulted in a mix of positive and negative impacts depending on the context of the conflict, the actors involved, and national and local capacity and resources. Mixed results also stem from the variety and range of regional and international interests that often claim a stake in the outcome of conflict resolution and statebuilding efforts.

Flowing from the above discussion, several gaps in present policy seem evident. Focus on these areas can offer entry points for better results while engaging with NSAGs in FCAS in the future. However, to be truly effective, it is important to implement these entry points with the full understanding of local realities, capacities and resources. The emphasis must be on developing an empirically-informed evidence base for policy. This "empirical-rootedness" can provide a stronger basis for planning peace and statebuilding interventions in a range of fragile, conflict affected and post-conflict environments. Better planned interventions would help engage with NSAGs more effectively and with a view to incorporating their role positively for harnessing local legitimacy, inclusiveness and the political will of all parties for building strong state-society relationships.

\subsection{Building states from the bottom-up}

A key lesson for future international engagement with NSAGs is to harness existing non-state forms of governance in their statebuilding efforts. Rather than replicating a top-down institutional model, statebuilding efforts must seek a "bottom-up" approach that results in a fusion of traditional and new institutional governance structures.

If the state is unable or unwilling to deliver justice or welfare services evenly to the civilian population (and to all groups within that population) it does not mean that these are entirely unprovided. As discussed in this paper, in several FCAS state functions have been assumed by rebel groups, local militias, guerrilla armies and customary authorities (Rapley, 2006). Although these actors may create greater insecurity, they may also create indigenous forms of legitimate political authority (Reno, 2008). Non-state and community-based security provision through local vigilante or community youth watch teams may prove more effective and trustworthy than new hybrid structures involving international and local actors (Persson and Kantor, 2011). Thus, in most FCAS weak or imperfect state authority can coexist territorially with nonstate forms of social authority (Rodgers, 2006; O'Donnell, 1993). These "hybrid political orders" result in the creation of mediated forms of statehood that can be effective and legitimate in pockets (Reno, 1998; Menkhaus, 2006).

A bottom-up statebuilding model is therefore advocated in states such as Afghanistan and DRC, where lack of capacity to deliver fundamental public services weakens state legitimacy. Lessons from the Afghan experience suggest that a heavy dependence on external forces, both for the assurance of security and for the improvement of service delivery, has indirectly obstructed legitimacy building by delaying improvement in the capacity of the state machinery. The National Solidarity Programme (NSP) that functions through community development councils can be regarded as the first steps towards a bottomup statebuilding process that includes securing public trust. Policy makers need to understand the construction of community support and indigenous legitimacy formation. If the community is taken as the root for public legitimacy it can help overcome deficiencies and corruption of procedural democracy (Takeuchi et al., 2011).

Statebuilders must seek to mainstream these existing structures through engagement with NSAGs to 
create legitimate institutions that work. This involves using participatory methodologies such as institutional diagramming analysis, rapid social assessments and social networking mapping before introducing structural and institutional reforms. For example, this was attempted in Liberia using a community-based recovery strategy (Richards et al., 2005; Bowd and Özerdem, 2010). By engaging community leaders in this bottom-up reconstruction process the efficacy and viability of reviving and preserving localised institutions can be ascertained. This process of bottom-up reconstruction can be initiated prior to the development of governance reform templates that often prove to be irrelevant to context, externally-imposed and illegitimate (Boettke et al., 2008).

\subsection{Including legitimate groups in peace settlements}

In order to be sustainable and inclusive, peace negotiations, peace settlements, disarmament of armed groups, elections, democratic transitions and societal reconciliation efforts require political will on the part of all conflicting groups. This means that NSAGs are significant players in both peace and statebuilding activities. They are stakeholders in the nature and quality of the peace, and wish to access the large volumes of international resources that support peace and statebuilding. However, most NSAGs are distrustful of the international community due to the latter's propensity to approach NSAGs from a counterterrorism framework (see above). As a result the main challenge for international peace building efforts is to build mutual confidence and trust through constructive dialogue.

Lessons from recent peacebuilding failures suggest that inclusive peace settlements, though beneficial in theory, may be problematic in practice. In the case of Liberia, key government positions went to former rebel commanders after the peace of 2003, perpetuating corruption and elite control over national and international resources. Hence participation or inclusion of all NSAGs in peace settlements can reinforce dependency on international efforts. Growing evidence suggests that to establish sustainable peace, negotiation processes must involve a thorough analysis of the legitimacy and peacebuilding potential of relevant stakeholders (OECD, 2010).

This analysis must focus on both horizontal dynamics (competing factions within the elite) and the vertical dynamics (the relationship between elites/rulers/authorities and people). To promote inclusiveness, progress in peacebuilding should be mapped and related to the agency and positive participation of actors involved. If the positive and negative agency of horizontal and vertical actors included in a peace settlement is monitored, it can provide important clues for future international engagement and policy on NSAGs. For instance, if progress in statebuilding is due to the involvement of external agencies, then it may be unsustainable in the long term. Similarly, if non-state actors are primary service providers, more robust political dialogue may be required with them. Top-down approaches, through their emphasis on "political settlement" and "legitimate politics", can bestow legitimacy on non-state security actors who may lack the power (traditional legitimacy) to enforce the peace. If external actors select their own regional allies to secure "political will" for peace they may empower certain groups (tribal or ethnic) at the expense of the legitimacy and inclusiveness that are key to strong state-society relations. The single sovereign approach is also inimical to inclusiveness (see Andersen, 2012). There is need for a deeper understanding of where the power of non-state security actors is derived from. If NSAGs derive power from civilian communities (support base) and foot soldiers (recruits) they are well positioned to bring public support and legitimacy to peace settlements.

\subsection{Adopt the institutionalisation before liberalisation model where appropriate}

According to the proponents of the institutionalisation before liberalisation model (IBL) (Paris, 2004) peace agreements should include provisions that institutionalise the role of former combatant organisations within state structures prior to beginning competitive electoral processes. The policy implications here are double-edged. On the one hand, it encourages the electoral participation of all potentially dangerous groups; on the other hand, political competition during elections can often be violent and divisive. For instance, political parties often rely on proxies, private militias and ex-combatants to capture votes. This 
captive constituency phenomenon then replaces open conflict but does not resolve political tensions (Bratton and Walle, 1997; Clapham, 1996; Mwenda and Tangri, 2005). Burundi, DRC, Ivory Coast, Liberia, and Sierra Leone provide ample evidence of this negative trend. These cases provide grounds for reconsidering the IBL model as the best form of political reconstruction in countries with unresolved intergroup conflict.

\subsection{Focus on the positive role of NSAGs in statebuilding}

Since 9/11 there has been an increasing tendency to view all armed actors as spoilers or terrorists and as a challenge to an established socio-political order. This negative perception does not reflect the true nature of NSAGs - their degree of social legitimacy, political roles and aspirations. NSAGs need to be viewed as providing alternatives to the state, and must be factored into political settlements through a careful monitoring of their agency and involvement in statebuilding. International engagement with NSAGs must develop appropriate indicators that can gauge the potential of NSAGs as agents of change that can play constructive roles in securing peace and building more legitimate states. The role of non-state lawenforcement actors merits greater policy attention in statebuilding. There is growing evidence of their positive role in statebuilding, as reviewed earlier. Similarly non-state governance structures have also strengthened and supported donor-assisted projects in FCAS. Drawing on this evidence base, international policy towards NSAGs in peace and statebuilding can initiate engagement with NSAGs even prior to the negotiation of a peace settlement. This engagement can focus on the role of legitimate NSAGs as positive statebuilding agents in the initial stages of stabilisation, rather than as spoilers that need to be accommodated in an all-inclusive peace settlement.

\subsection{Acknowledging the importance of regional peacebuilding in successful statebuilding}

The role of international and regional state sponsors of conflict continues to be poorly accounted for in post-conflict statebuilding. States that themselves have good governance may externalise their own conflicts or pursue military goals that result in regional fragility, as in Rwanda and Ethiopia. Apart from the regional flow of mercenaries and weapons, and the use of cross-border sanctuaries for launching attacks, global flows - such as diaspora support, and use of social media and other forms of technology for influencing world opinion - make it imperative to widen the scope of engagement. Regional power brokers (strong states) may even mortgage territory and resources of one state on behalf of or in concert with another for exercising control over proto/shadow states. Hence "bad neighbourhoods" can be detrimental to statebuilding success. In the light of the instability created by the transnational operations and support bases of a number of NSAGs the importance of regional peacebuilding for successful statebuilding cannot be ignored. International donors must adopt a strategy of effective regional peace building prior to individual statebuilding. Regional organisations that focus on security and peacebuilding - such as the Economic Community of West African States (ECOWAS), The Association of Southeast Asian Nations (ASEAN) and African Union - provide platforms for engaging with NSAGs through multiple government channels in regional conflict sub-systems. Thus, by harnessing existing regional dialogue frameworks or by emphasising a regional peacebuilding process (that creates norms against sponsoring militias/proxies) through relevant forums, the international community can further strengthen positive engagement with NSAGs in peace and statebuilding. 


\section{Conclusions and avenues for future research}

\subsection{Conclusions}

In fragile states, foundational factors such as geography, the history of state and society formation as well as regional and international influences underlie the perpetuation of informal and non-state forms of governance, often belonging to sub-groups within the state, that are difficult to mainstream into the public sector. The leaders of these groups, which may be tribes, ethnic groups or social classes, are often vying for the same pool of national resources (natural wealth, representation and power distribution) and international contributions (donor aid for development, reconstruction and governance reform). As a result, fragile states are often characterised by a complex division of revenues (Anten et al., 2012). Reconciling differences and rivalries among these groups in a short span of international engagement can be a frustrating and intractable task.

NSAGs are key actors in post-conflict societies for a variety of reasons, not least because they carry out sovereign functions within internationally recognised states (Beswick, 2009). Rebel groups are often organised by elites or marginalised ethnic and tribal leaders seeking political representation or share in the political process. Statebuilding projects require co-operation of subnational elites along with rebel leaders, power brokers and ex-combatants for success of liberal reforms. By engaging with non-state armed groups and by providing them with incentives to disarm and demobilise, or by offering them positions in a new national government, international actors provide these subnational elites resources to maintain the autonomy and influence they secured during the conflict years. This results in a situation of strategic interaction and interdependence. The overall result is the linking of domestic politics and the root causes of conflicts as the defining framework for the relationship between international and local actors including non-state armed groups.

However, programmes to create centralised democratic states remain largely top-down and externally driven, and are complicated by the multiple sovereignties of NSAGs. If power sharing agreements include groups that have leadership schisms or intra-group competition between different tribal factions or personalities representing them there can result further fragmentation, which will in turn restore the inherent fragility and weakness of the state. There is increasing recognition that the push for liberal democracy as part of international statebuilding in FCAS may result in electoral violence and use of private militias or ex-combatants to capture electorates (See Utas and Christensen, 2008, on Sierra Leone's post-war elections). As a result, accommodating conflicting elites through peace settlements may not always result in liberal democracy and the resolution of inter-group competition within a sustainable peace (Barnett and Zürcher, 2009), but in violent competition over resources, markets and ballots.

Conflict is part of the state formation process, and in line with this historical reality, several non-state armed groups (NSAGs) take on the role of "proto states". These actors may offer security, protection, governance, justice and other basic services - which the government authorities may be failing to provide. Mobilising community level support and inclusion in favour of peace and statebuilding appears to have a persuasive effect on NSAGs given that communities form the basis for their domestic legitimacy. The prevailing opinion of their support base may be used to push them to the peace negotiations table. This is more likely to be successful where NSAGs rely on civilians for resources, support and legitimacy. However, the fragmentation of NSAGs can prove to be important challenge to such an approach, since it would invalidate any peace and statebuilding agreements previously made and necessitate the renegotiation of terms.

Donor-recipient relations in post-conflict reconstruction are equally complex. Despite efforts to synergise efforts and expectations, divergence from goals is often unavoidable. The contest remains between local ownership and external direction. A certain amount of handholding can be beneficial; however over- 
dependency can undermine the rationale for state-building efforts. The GWOT-related counter-terrorism pursuit has exacerbated this problem by creating excessively close relationships between donors and their ally states, while delegitimising NSAGs. The consequent over-dependence of ally governments on donor resources reduces their dependence on their domestic populace, which leads to lower levels of accountability, heightened state fragility and greater chances of conflict. Counterterrorism efforts have also encouraged greater transnational co-operation between different types of NSAGs and dependence on criminal activity to finance operations.

Potential entry points and policy guidelines for donors include the need for "bottom-up" statebuilding efforts in capacity trap countries like Afghanistan and DRC, the inclusion of legitimate groups in peace settlements and greater focus on the positive role of NSAGs in statebuilding. Further entry points for policy dialogue include recognition of diversity in state-society relationships and the need for "good enough institutions". Finally, for statebuilding efforts to be successful they must be framed within a broader template of regional peace building to prevent the externalisation or spillover of conflict and fragility.

\subsection{Areas for further research}

It is hoped that this paper will serve to provide clues for the development of more a comprehensive, evidence-based knowledge pool. This can provide stronger and more effective frameworks of action that can help reduce the negative impacts of NSAGs activity in FCAS. The research agenda for NSAGs should be broadened not only with respect to the groups that we study, but to include the definition of benchmarks and scales that allow us to rank the nature, type and intensity of threats and identify potential partners in peace and statebuilding efforts. These analytical tools can then be related to different types of NSAGs currently identified as important stakeholders in FCAS. The resulting categorisation can provide a solid, empirical basis for developing and applying policy responses. Krause and Milliken (2009) have underlined the need to refine the frameworks, methods and approaches applied to the study of NSAGs. In addition to this recommendation there are five specific gaps in our understanding that merit further research on NSAGs and their role in conflict and fragility:

1) The intensity and types of threats posed by different NSAGs. To understand these better, it will be useful to develop a typology of threats that clearly identifies them and relates them to their true and anticipated intensity.

2) The lack of open resource literature on how far different types or categories of NSAGs co-operate with each other over resources and capacities. This lack of targeted literature on the subject is partly due to the covert nature of organisational financing that is used by NSAGs. This angle merits further research but will require access to intelligence sources.

3) The inter-linkages between NSAGs and other international factors such as transnational crime, diaspora flows, aid, trade and small arms trafficking that exacerbate conflict and fragility in multifarious ways. Open source literature on this subject is weak. This strand has to be developed through more targeted research projects addressing this gap in current understanding of global factors.

4) The impact of resources provided through counter-terrorism co-operations, such as intelligence sharing, on dissipating the strength and role of NSAGs. Counter-terrorism aid has in some cases fed the capacity of these groups as discussed above. Statistical and in-country, field-level understanding of this aspect is required to clearly identify how aid/resource diversion may be exacerbating global factors for conflict and fragility.

5) The ways in which abuse by rebel groups during conflict can influence post-conflict reintegration, social reconciliation and community-combatant relations. Cross-country case studies in particular could strengthen current understanding of rebel group transition to mainstream politics and as sources of post-conflict political legitimacy. 


\section{Bibliography}

Abuza, Z. (2003), "Funding Terrorism in Southeast Asia: The Financial Network of Al Qaeda and Jemaah Islamiya", Contemporary Southeast Asia: A Journal of International \& Strategic Affairs, 25 (2): 169199.

Achvarina V. and S. Reich (2006), "No Place to Hide: Refugees, Displaced Persons and the Recruitment of Child Soldiers", International Security, Summer 2006, 31 (1): 127-164.

Ali, A. (2010), Socio-Economic Cost of Terrorism: A Case Study of Pakistan, available at http://spaces.brad.ac.uk:8080/download/attachments/748/Brief+57B.pdf (accessed 19 May 2012).

Anant, A. (2011), Non-state Armed Groups in South Asia, Pentagon Press, New Delhi.

Andersen, L. R. (2012), "The Liberal Dilemmas of a People-centred Approach to Statebuilding", Conflict, Security and Development, 12 (2): 103-121.

Anderson, M. (1999), Do No Harm, Rienner, Boulder, CO.

Anten, L., I. Briscoe and M. Mezzera (2012), The Political Economy of State-building in Situations of Fragility and Conflict: from Analysis to Strategy, Conflict Research Unit (CRU), Clingaedal.

Ayres, R. W. (2006), "No Peace at Any Price: The Effectiveness of Spoilers in Intrastate Conflicts", paper presented at the 47th Annual Meeting of the International Studies Association, San Diego, CA, 2225 March.

Azam, J.P. and Delacroix, A. (2006), "Aid and the Delegated Fight Against Terrorism", Review of Development Economics, 10: 330-344.

Azam, J.P. and V. Thelen (2008), "The Roles of Foreign Aid and Education in the War on Terror", Public Choice, 135: 375-397.

Azam, J.P. and V. Thelen (2010), "Foreign Aid vs. Military Intervention in the War on Terror", Journal of Conflict Resolution, 54: 237-261.

Baker, B. (2010), "Law Enforcement Capacity-Building in African Post Conflict Communities", PRISM, 2 (3), at www.ndu.edu/press/law-enforcement-african-postconflict.html (accessed 20 April 2012).

Ballentine, K. and J. Sherman (2003), The Political Economy of Armed Conflict: Beyond Greed and Grievance, Lynne Rienner Publishers, Boulder, CO.

Bandyopadhyay, S., T. Sandler and J. Younas (2009), "Foreign Aid as Counterterrorism Policy", Research Division Federal Reserve Bank of St. Louis Working Paper 2009-021B, Federal Reserve Bank of St. Louis, MO, available at $h t t p: / / r e s e a r c h . s t l o u i s f e d . o r g / w p / 2009 / 2009-021 . p d f$ (accessed 17 January 2012).

Bapat, N (2006), "State Bargaining with Transnational Terrorist Groups", International Studies Quarterly, 50 (1) March, pp. 213-230.

Bapat, N.A. (2011), "Transnational Terrorism, US Military Aid, and the Incentive to Misrepresent", Journal 
of Peace Research, 48 (3): 303-318.

Barnett, M and C. Zürcher (2009), "The Peacebuilder's Contract: How external statebuilding reinforces weak statehood", in Paris R. and T. D. Sisk (eds.), The Dilemmas of Statebuilding. Confronting the contradictions of postwar peace operations, Routledge, London.

Basile, M. (2004), "Going to the Source: Why Al Qaeda's Financial Network Is Likely to Withstand the Current War on Terrorist Financing", Studies in Conflict \& Terrorism, 27 (3): 169-185.

Beardsley, K. and B. McQuinn (2009), "Rebel Groups as Predatory Organizations: The Political Effects of the 2004 Tsunami in Indonesia and Sri Lanka", Journal of Conflict Resolution, 53: 624.

Beswick, D. (2009), "The Challenge of Warlordism to Post-Conflict State-Building: The Case of Laurent Nkunda in Eastern Congo", The Round Table: The Commonwealth Journal of International Affairs, 98 (402): 333-346.

Bhatt, C. (2007), "Frontlines and Interstices in the Global War on Terror", Development and Change, 38 (6): 1073-1093.

Biersteker, T. J. and S.E. Eckert (2007), Countering the Financing of Terrorism, Taylor and Francis, London and New York.

Billingslea, W. (2004), "Illicit Cigarette Trafficking and the Funding of Terrorism", Police Chief, 71 (2): 49_ 56.

Boettke, P.J. Coyne, C.J. and Leeson, P.T. (2008), "Institutional Stickiness and the New Development Economics", American Journal of Economics and Sociology, 67 (2), pp. 331-358.

Bowd, R and A. Özerdem (eds.) (2010), Participatory Research Methodologies in Development and Post Disaster/Conflict Reconstruction, Ashgate, London.

Bradbury, M. and Kleinman, M. (2010), Winning Hearts and Minds? Examining the relationship between aid and security in Kenya, Feinstein International Center: Tufts University, Boston.

Bratton, M. and N. van de Walle (1997), Democratic Experiments in Africa: Regime Transitions in Comparative Perspective, Cambridge University Press, Cambridge.

Brinkerhoff, D. (2007), Capacity Development in Fragile States, European Centre for Development Policy Management, Maastricht.

Bruderlein, C. (2000), The Role of Non-state Actors in Building Human Security: The case of armed groups in intra-state wars, background paper for Centre for Humanitarian Dialogue, Geneva.

Bruderlein, C., A. Clapham, M-M. Mohamedou and K. Krause (2007), Transnational and Non-State Actors: Issues and Challenges, Harvard University, at www.tagsproject.org/index.cfm?fuseaction=page.viewPage\&pagelD=793\&nodeID=12 (accessed 18 February 2012)

Bryden, A. and H. Hänggi (eds.) (2005), Security Governance in Post-Conflict Peacebuilding, Geneva Centre for the Democratic Control of Armed Forces (DCAF), at www.dcaf.ch/_docs/Yearbook2005/Chapter3.pdf (accessed 13 January 2012).

Chabal, P. and J-P. Daloz (1999), Africa Works: The Political Instrumentalization of Disorder, International 
African Institute in association with James Currey and Indiana University Press, Bloomington, IN.

Clapham, C. (1996), Africa and the International System: The Politics of State Survival, Cambridge University Press, Cambridge.

Clapham, C. (ed.) (1998), African Guerrillas, James Currey, Oxford.

Collier, P. (1994), "Demobilization and Insecurity: A study in the economics of the transition from war to peace", Journal of International Development, 6.

Collier, P. and A. Hoeffler (2004), "Greed and Grievance in Civil War", Oxford Economic Papers, 56 (4): 563-595.

Collier, P. and Hoeffler A. (1998), "On Economic Causes of Civil War", Oxford Economic Papers 50, Oxford University Press, London.

Collier, P., A. Hoeffler and M. Soderbom (2008), "Post-conflict Risks", Journal of Peace Research, 45 (1): 461-478.

Conciliation Resources (2012), Mediation and Engaging with Proscribed Armed Groups, Summary of expert meeting: 29 March, at www.globalct.org/images/content/pdf/summaries/Mediation_engaging_with_proscribed_armed_grou ps.pdf (accessed 19 May 2012).

Croissant, A. and D. Barlow (2007), "Following the Money Trail: Terrorist Financing and Government Responses in Southeast Asia", Studies in Conflict \& Terrorism, 30 (2): 131-156.

DCAF and Geneva Call (2011), Armed Non-state Actors: Current Trends and Future Challenges, Geneva Centre for the Democratic Control of Armed Forces, Geneva, www.dcaf.ch/Project/Horizon2015/(show)/publications (accessed 6 October 2012)

Dudouet, V. (2010), "Mediating Peace with Proscribed Armed Groups", USIP Special Report No. 239, United States Institute of Peace, Washington DC.

Dudouet, V. (2011), "Nonviolent Resistance in Power Asymmetries", in Austin B., M. Fischer and H. J. Gießmann (eds.), Advancing Conflict Transformation. The Berghof Handbook II, Barbara Budrich Publishers, Opladen and Farmington Hills.

Dudouet, V., Giessmann, H.J. and Planta, K. (2012), From Combatants to Peacebuilders: A case of inclusive, participatory and holistic security transitions, Berghof Foundation, Berlin.

Eriksen, S. (2009), "The Liberal Peace Is Neither: Peacebuilding, State building and the Reproduction of Conflict in the Democratic Republic of Congo", International Peacekeeping, 16 (5): 652-666.

Fakuda-Parr, S. (2007), "Rethinking the Policy Objectives of Development Aid: From Economic Growth to Conflict Prevention", UNU-WIDER Research Paper, 32, at

Fleck, R.K. and C. Kilby (2010), "Changing Aid Regimes? U.S. Foreign Aid from the Cold War to the War on Terror", Journal of Development Economics, Elsevier, 91 (2): 185-197.

Fortna, V. P. (2003), "Scraps of Paper? Agreements and the Durability of Peace", International Organization, 2003, 57 (2): 337-372. 
Fortna, V. P. (2004), Peace Time: Cease-Fire Agreements and the Durability of Peace, Princeton University Press, Princeton, NJ.

Gaibulloev, K. and T. Sandler (2008), "Growth Consequences of Terrorism in Western Europe", Kyklos, 61: 411-424.

Gear, S. (2002), "Wishing Us Away: Challenges Facing Ex-Combatants in the 'New' South Africa", in Violence and Transition Series, 8, at www.csvr.org.za/papers/papvtp8a.htm (accessed 20 July 2011).

Geneva Academy of International Humanitarian Law and Human Rights (2010), Armed Non-state Actors and International Norms: Towards a better protection of civilians in armed conflict, Summary of initial research and discussions during an expert workshop, Geneva, March 2010, available at www.adhgeneva.ch/docs/reports/armednonstateactors.pdf

Geneva Call and DCAF (2011), Armed Non-State Actors: Current Trends and Future Challenges, Geneva Centre for the Democratic Control of Armed Forces, Geneva, available online at www.dcaf.ch/Publications/Armed-Non-State-Actors-Current-Trends-Future-Challenges (accessed 15 May 2012).

Ghani, A. and C. Lockhart (2008), Fixing Failed States, Oxford University Press, Oxford.

Gregory, D. (2012), Supplying War in Afghanistan: the frictions of distance, Open Democracy, online at www.opendemocracy.net/derek-gregory/supplying-war-in-afghanistan-frictions-of-distance (accessed 13 July 2012).

Hansen, S.J. (2003), "Warlords and Peace Strategies: The Case of Somalia", Journal of Conflict Studies, 23 (2), available at http://journals.hil.unb.ca/index.php/JCS/article/view/217 (accessed 15 April 2012).

Hartzell, C. and M. Hoddie (2003), "Institutionalizing Peace: Power Sharing and Post-Civil War Conflict Management", American Journal of Political Science, 47 (2): 318-332.

Hazen, J. M. (2010), "Understanding Gangs as Armed Groups", International Review of the Red Cross, 92: 369-386.

Heine, J. and R. Thakur (eds.) (2011), The Dark Side of Globalization, United Nations University Press, Tokyo.

Hill, G. (2010), "What is Happening in Yemen?", in Survival: Global Politics and Strategy, 52 (2): 105-116.

Hofmann, B. (2004), "The Changing Face of Al Qaeda and the Global War on Terrorism", Studies in Conflict \& Terrorism, 27 (6): 549-560.

Hofmann, B. (2006), Inside Terrorism, Columbia University Press, NY.

Hofmann, C. (2006), "Engaging Non-State Armed Groups in Humanitarian Action", International Peacekeeping, September 2006, 13 (3): 396-409.

Hofmann, C. and U. Schneckener (2011), "NGOs and Nonstate Armed Actors: Improving Compliance with International Norms", USIP Special Report 284, United States Institute of Peace (USIP), Washington. 
Holmquist, C. (2005), "Engaging Armed Non-state Actors in Post-conflict Settings", in Bryden A. and H. Hanggi (eds.), Security Governance in Post-conflict Peacebuilding, Geneva Centre for the Democratic Control of Armed Forces, Geneva, Switzerland.

IDPS (International Dialogue on Peacebuilding and Statebuilding) (2011), A New Deal for Engagement in Fragile States, IDPS, OECD, Paris, available at www.oecd.org/international\%20dialogue/anewdealforengagementinfragilestates.htm

Jarstad, A. K. and D. Nilsson (2008), "From Words to Deeds: The Implementation of Power-Sharing Pacts in Peace Accords", Conflict Management and Peace Science, 25 (3): 206- 223.

Keen, D. (1998), The Economic Functions of Violence in Civil Wars, Adelphi Paper No. 320, International Institute for Strategic Studies, London.

Klapdor, D. (2009), "From Rebels to Politicians: Explaining Rebel to Party Transformations after Civil War: The Case of Nepal", DESTIN, WP, 9/94, London School of Economics, London, available at www2.Ise.ac.uk/internationalDevelopment/pdf/WP94.pdf

Krahmann, E. (2005a), "Security Governance and Networks: New theoretical perspectives in transatlantic security", Cambridge Review of International Affairs, 18 (1): 19- 34.

Krause, K. and J. Milliken (2009), "Introduction: The Challenge of Transnational and Non-State Armed Groups", Contemporary Security Policy, 30 (2): 202-220.

Kriger, N. (2006), "From Patriotic Memories to 'Patriotic History' in Zimbabwe, 1990-2005”, Third World Quarterly, 27 (6): 1151-1169.

Kydd, A. and B. Walter (2002), "Sabotaging the Peace: The Politics of Extremist Violence", International Organization, 56 (2): 263-296.

Levitt, M. A. (2002), "The Political Economy of Middle East Terrorism", Middle East Review of International Affairs, 6 (4): 49-65.

Lorentzen, L.A. and J. Turpin (eds.) (1998), The Women and War Reader, New York University Press, New York.

Lyons, T. (2005), Demilitarizing Politics: Elections on the Uncertain Road to Peace, Lynne Reinner, Boulder.

Lyons, T. (2009), Peacebuilding, Democratization, and Transforming the Institutions of War, Routledge, London.

Mac Ginty, R. (2011), International Peacebuilding and Local Resistance: Hybrid forms of peace, Palgrave, London.

Makarenko, T. (2004), "The Crime-terror Continuum: Tracing the interplay between transnational organized crime and terrorism", Global Crime, February 2004, 6 (1): 129-145.

Mann, M. (1984), "The Autonomous Power of the State: Its origins, mechanisms and results", Archives Européennes de Sociologie, 25 (2): 185-213.

Menkhaus, K. J. (2006), "Governance without Government in Somalia: Spoilers, Statebuilding, and the 
Politics of Coping", International Security 31 (3): 74-106.

Metelits, C. (2010), Inside Insurgency: Violence, Civilians, and Revolutionary Group Behaviour, New York University Press, New York.

Mulaj, K. (ed.) (2010), Violent Non-State Actors in World Politics, Hurst and Columbia University Press, London and New York.

Müller, T.R. (2012), "From Rebel Governance to State Consolidation - Dynamics of loyalty and the securitisation of the state in Eritrea", Geoforum, February 2012, 1-11.

Mwenda, A. M. and R. Tangri (2005), "Patronage Politics, Donor Reforms, and Regime Consolidation in Uganda", African Affairs, 416: 449-467.

Newman, E. and Richmond, O. (2006), "Peace building and Spoilers", Conflict, Security and Development, 6 (1) April, pp. 101-110.

Nilsson, A. (2008), Dangerous Liasions, Why Ex-combatants Return to Violence: Cases from the Republic of Congo and Sierra Leone, Uppsala University, Uppsala.

ODI/HPG/SOAS (2011), "Politicisation and Securitisation of Aid: Challenges of Humanitarian Space in Somalia", Meeting Summary, Roundtable Meeting Series on Humanitarian Space, Meeting Four, Nairobi, 14 February, available at www.odi.org.uk/events/docs/4654.pdf (accessed 19 July 2012).

OECD (2008), Concepts and Dilemmas of Statebuilding in Fragile Situations: From Fragility to Resilience, OECD Publishing, Paris

OECD (2011a), Supporting Statebuilding in Situations of Conflict and Fragility: Policy Guidance, DAC Guidelines and Reference Series, OECD Publishing.

OECD (2011b), International Engagement in Fragile States: Can't We Do Better?, OECD Publishing, Paris.

OECD/DAC (2010), Peacebuilding and Statebuilding Priorities and Challenges: A Synthesis of Findings from Seven Multi-Stakeholder Consultations, Secretariat of the International Dialogue on Peacebuilding and Statebuilding, OECD, Paris.

Orjuela, C. (2008), "Distant Warriors, Distant Peace Workers? Multiple diaspora roles in Sri Lanka's violent conflict", Global Networks, 8 (4): 436-452.

Özerdem, A. and S. Podder (2011), "Disarming Youth Combatants: Mitigating Youth Radicalization and Violent Extremism", Journal of Strategic Security, December 2011, 4 (4): 63-80.

Paris, R. (2004), At War's End: Building Peace after Civil Conflict, CUP, Cambridge.

Paris, R. and T.D. Sisk, (2009), The Dilemmas of Statebuilding: Confronting the Contradictions of Postwar Peace Operations, Routledge, London.

Persson, M and Kantor, A. (2011), "Liberian Vigilantes: Informal security providers on the margins of the SSR", in M. Ekegren and G. Simons (eds), The Politics of SSR: Challenges and Opportunities for the EU's Global Role, Ashgate, London.

Podder, S. (2010), Child Soldier Reintegration Outcomes in Post Conflict Environments: An Analysis of 
Re-recruitment Trends in the Liberian Civil Wars, PhD Thesis, University of York, UK.

Podder, S. (2012), "From Recruitment to Reintegration: Communities and Ex-combatants in Post-Conflict Liberia", International Peacekeeping. 19 (2): 186-202.

Policzer, P. (2005), Neither Terrorists nor Freedom Fighters, paper presented at the International Studies Association Conference, Honolulu, 3-5 March.

Quinlan, P. J. (2012), "Pakistan: A Conflicted Ally in the Fight Against Terrorism Since 9/11", Global Security Studies, Winter 2012, 3 (1), available at

Reno, W. (2000), "Clandestine Economies, Violence and States in Africa", Journal of International Affairs, Spring 53 (2): 433-59.

Reno, W. (2006), "Patronage Politics and the Behaviour of Armed Groups", Civil War, 9 (4): 324-342.

Reno, W. (n.d.), "Complex Operations in Weak and Failing States: The Sudan Rebel Perspective", Prism, 1 (2): 111-122

Reveron, D. (2006), Old Allies, New Friends: Intelligence Sharing in the War on Terror, Orbis 50 (3): $453-$ 468.

Richards, P. et al. (2005), "Community Cohesion in Liberia: A Post-war Rapid Social Assessment", World Bank Social Development Papers, 21, The World Bank, Washington DC.

Rodgers, D. and R. Muggah (2010), "Gangs as Non-State Armed Groups", in Krause K. (ed.), Armed Groups and Contemporary Conflicts, Routledge, London.

Roth, M. P. and M. Sever (2007), "The Kurdish Workers Party (PKK) as Criminal Syndicate: Funding Terrorism through Organized Crime, A Case Study", Studies in Conflict \& Terrorism 30 (10): 901920.

Sageman, M. (2004), Understanding Terror Networks, University of Pennsylvania Press, Philadelphia.

Sageman, M. (2008), Leaderless Jihad: Terror Networks in the Twenty-first Century, University of Pennsylvania Press, Philadelphia.

Salehyan, I. (2009), Rebels without Borders: Transnational Insurgencies in World Politics, Cornell University Press, Ithaca, NY.

Sanderson, T. M. (2004), "Transnational Terror and Organized Crime: Blurring the Lines", SAIS Review 24 (1): 49-61.

Schneckener, U. (2011), "Dealing with Armed Non-State Actors in Peace and State Building, Types and Strategies", in Benedek, W., C. Daase, V. Dimitrijevic and P. van Duyne (eds.), Transnational Terrorism, Organized Crime and Peace-Building. The State of the Art in Human Security in the Western Balkans, Palgrave Macmillan, London.

Scott, Z. (2007), "Literature Review on Statebuilding", Governance and Social Development Resource Centre, University of Birmingham, at www.gsdrc.org/docs/open/hd528.pdf (accessed 17 March 2012).

Shain, Y. (2002), "The Role of Diasporas in Conflict Perpetuation of Resolution", in SAIS Review, 
Summer/Fall 2002, 22 (2): 115-144.

Shepard, D. (2010), Statebuilding, Externalisation and National Interests: Beacons of good governance or exporters of violence? London School of Economics, London.

Simon, S. and D. Benjamin (2001), "The Terror", in Survival, 43: 5-18.

Smith, H. and P. Stares (eds.) (2007), Diasporas in Conflict: Peace-makers or peace-wreckers?, United Nations University Press, Tokyo, New York and Paris.

Soderberg, M. (2007), From Rebellion to Politics: The Transformation of Rebel Groups to Political Parties in Civil War Peace Processes, Uppsala University, Uppsala, Sweden.

Spence, K. (2005), "World Risk Society and War against Terror", in Political Studies, 53: 284-302.

Sriram, C. (2008), Peace as Governance: Power Sharing, Armed Groups, and Contemporary Transitions in Comparative Perspective, Palgrave MacMillan, Basingstoke.

Sriram, C. and J. Herman (2009), "DDR and Transitional Justice: Bridging the divide?", Conflict, Security, and Development, 9 (4): 455-474.

Staniland, P. (2011), "States, Insurgents, and Wartime Political Orders", Perspectives on Politics, (forthcoming).

Stedman, J. S. (2001), "Implementing Peace Agreements in Civil Wars: Lessons and Recommendations for Policy Makers", IPA Policy Paper Series on Peace Implementation, International Peace Academy, New York.

Stedman, S. (1997), Spoiler Problems in Peace Processes, International Security, 22 (2), pp. 5-53.

Stovel, L. (2008), "There's no Bad Bush to Throw Away a Bad Child: Tradition-inspired reintegration in post-war Sierra Leone", in Journal of Modern African Studies. 46 (2): 305-324.

Sullivan G. and B. Hayes (2010), Blacklisted: Targeted Sanctions, Pre-emptive security, and fundamental rights, European Centre for Constitutional and Human Rights, Berlin.

Takeuchi, S., R. Murotani and K. Tsunekawa (2011), "Capacity Traps and Legitimacy Traps: Development Assistance and State Building in Fragile Situation", in Kharas, H. K. Makino and W. Jung (eds), "Catalyzing Development: A New Vision for Aid, Brookings Institution Press", Washington, DC, available at http://jica-ri.jica.go.jp/publication/assets/Chapter\%206.pdf (accessed 17 January 2012).

Tams, C. J. (2009), "The Use of Force against Terrorists", European Journal of International Law, 359, http://ejil.oxfordjournals.org/cgi/reprint/20/2/359

Ucko, D. (2008), "Militias, Tribes and Insurgents: The Challenge of Political Reintegration in Iraq", Conflict, Security \& Development, 8 (3): 341-373.

UNSC (United Nations Security Council) (2007), Update Report on Security Sector Reform, UNSC, New York.

UNSC (2009), Report of the Secretary General on the Protection of Civilians in Armed Conflict, S/2009/277, UNSC, New York, available at www.genevacall.org/resources/official- 
documents/2001-2010/2009-29may-unsc.pdf, (accessed 16 May 2012).

US House of Representatives Majority Staff (2010), Warlord, Inc.: Extortion and Corruption along the U.S. Supply Chain, Majority Staff Report to Subcommittee on National Security and Foreign Affairs, available at http://media.washingtonpost.com/wp-srv/world/documents/warlords.pdf

Utas, M. and M. M. Christensen (2008), "Mercenaries of Democracy: The 'politrix' of remobilized combatants in the Sierra Leone 2007 General Elections", African Affairs, 107 (429): 515-539.

Uvin, P. (2008), "Local Governance after War: Some Reflections on Donor Behaviour in Burundi”, Praxis, 23: $109-122$.

Vinci, A. (2009), Armed Groups and the Balance of Power: The International Relations of Terrorists, Warlords and Insurgents, Routledge, London and New York.

Walter, B. F. (1997), "The Critical Barrier to Civil War Settlement", International Organization, 51 (3): $335-$ 364.

Walter, B. F. (1999), "Designing Transitions from Civil War: Demobilization, Democratization, and Commitments to Peace", in International Security, 24 (1): 127-155.

Walter, B. F. (2004), "Does Conflict Beget Conflict? Explaining Recurring Civil War", in Journal of Peace Research, 41 (3): 371-88.

Walter, B. F. (2010), "Conflict Relapse and the Sustainability of Post-conflict Peace", WDR 2011 Background Report, at http://wdr2011.worldbank.org/sites/default/files/pdfs/WDR\%20Background\%20Paper_Walter_0.pdf

Weinstein, J. (2007), Inside Rebellion: The Politics of Insurgent Violence, Cambridge University Press, Cambridge.

World Bank (2011), World Development Report, Overview online at http://wdr2011.worldbank.org/sites/default/files/WDR2011_Overview.pdf (accessed 16 October 2011).

Zahar, M. (2000), "Protégés, Clients, Cannon Fodder: Civilians in the calculus of militias", in International Peacekeeping, 7 (4): 107-128.

Zahar, M. (2003), "Reframing the Spoiler Debate in Peace Processes", in Darby, J. and R. Mac Ginty (eds), Contemporary Peacemaking: Conflict, Violence and Peace Processes, Palgrave-Macmillan, Basingstoke. 
